\title{
The Chairman or the Board? Appointments at Multimember Agencies
}

\author{
SEAN CROSTON*
}

\section{TABLE OF CONTENTS}

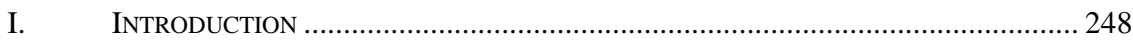

II. A BRIEF History of THE DEPARTMENT HEAD PROVISION ................................ 250

III. The Origin And Development of Multimember Agencies

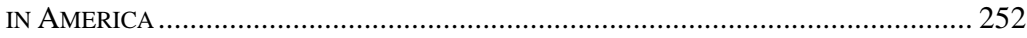

IV. CHAIRMEN's USE OF APPOINTMENT AUTHORITY WITHIN

MulTiMEMBER AgENCIES ............................................................................... 256

V. FREE ENTERPRISE Fund V. PUBLIC Co. ACCOUNTING OVERSIGHT BOARD .............. 266

VI. WHO ARE THE “INFERIOR OfFICERS” AT Multimember AgEnCIES? .................... 268

VII. FREE ENTERPRISE FUND AND CURRENT MULTIMEMBER AGENCY

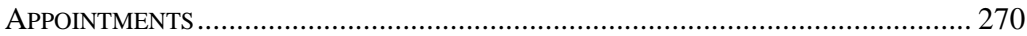

VIII. What ABout the “ApProbation Rule” and Removal Powers? ..................... 273

IX. DEALING WITH THE EFFECTS OF FREE ENTERPRISE FUND ................................... 275

X. APPENDIX: CURRENT APPOINTMENT MODELS FOR INFERIOR OfFICERS in Multimember Agencies

* (C) 2014 Sean Croston. Sean Croston is an attorney practicing in Washington, D.C. The views expressed in this Article are his alone and do not represent the views of any other person or entity. The Author received his J.D. in 2007 from the William \& Mary School of Law and wishes to thank Kent Barnett, Michael Rappaport, Steven Crockett, and Muriel and Charles Croston for their help and support. 
"No points of our fundamental law are more difficult than those involved in this whole subject of appointments."1

—Attorney General Hugh Legaré

\section{INTRODUCTION}

For the past 130 years, Congress has alternated between two competing structural visions of ideal administrative agency design-singleadministrator versus multimember organization. Over time, Congress has frequently reacted to strong arguments from both sides by approving various arrangements that conflate the two models, particularly with respect to the important but often overlooked authority to appoint "inferior Officers" within multimember agencies. In many cases, the chairmenor their equivalent - of these multimember boards and commissions retain some or all power to select high-ranking agency staff, whereas their fellow board or commission members have authority over agency rulemaking, adjudication, and other key functions. ${ }^{2}$ Although such power-sharing arrangements may have kept the peace in some sense for many years, recent events call into question the constitutional integrity of these mixedmanagement models.

Most importantly, on June 28, 2010, the Supreme Court issued its decision in Free Enterprise Fund v. Public Co. Accounting Oversight Board, a hotly contested 5-4 ruling involving several challenges to the appointment and removal of the Public Company Accounting Oversight Board at the Securities and Exchange Commission (SEC). ${ }^{3}$ The slip opinion and Justice Breyer's accompanying dissent ran over 100 pages, many of them disputing controversial "for cause" removal standards at independent agencies. ${ }^{4}$ But two interesting paragraphs near the end of the majority opinion have received little attention in subsequent analyses. These paragraphs settled a fairly novel challenge to the board appointments, which alleged that they were invalid because they were effective only after the SEC Chairman obtained the full Commission's approval, despite the

1. Appointment and Removal of Inspectors of Customs, 4 Op. Att'y Gen. 162, 164 (1843).

2. See infra Appendix (listing current appointment models within multimember federal agencies).

3. 130 S. Ct. 3138 (2010).

4. Free Enter. Fund v. Pub. Co. Accounting Oversight Bd., No. 08-861, slip op. (U.S. 2010). 
Constitution's Appointments Clause, which provides that "the Heads of Departments" may appoint "inferior Officers" within their agencies. ${ }^{5}$

In the course of rejecting this particular challenge, the Court set forth sensible new criteria for identifying the "Head" that is constitutionally responsible for making appointments of senior staff within a multimember agency. Namely, the "Head" is generally the person or entity that sets the agency's internal policies and has final say over the exercise of the agency's rulemaking, adjudicatory, and investigatory powers. ${ }^{6}$ But upon applying these standards to the organizational structures of current multimember agencies, it becomes relatively clear that the constitutional heads of all of these agencies are their respective boards or commissions, acting jointly. ${ }^{7}$ This conclusion casts serious doubt upon the constitutionality of a number of chairman-initiated and chairman-controlled appointment schemes long provided by statute.

In short, the Court's reasoning suggests that only the purest forms of the two competing organizational models will pass constitutional muster: a full multimember commission or board, acting jointly, must direct all appointments and removals of subordinate officers, or an agency must be controlled by a single administrator who likewise directs all appointments and removals of subordinate officers. The currently popular half-and-half model whereby multimember agency chairmen control appointments and removals or have the sole power to initiate those appointments or removals does not appear to comply with the Appointments Clause, as interpreted by the Court.

In addition, the Court's reasoning raises new questions about the constitutionality of the frequently used "approbation" model, whereby multimember boards or commissions cannot initiate and may only approve inferior officer appointments or removals, which must be initiated by their chairmen. These conclusions could have far-reaching effects if litigators recognize and begin to rely upon the Supreme Court's standards set forth in Free Enterprise Fund.

5. See id. at 3163; see also U.S. ConsT. art. II, § 2, cl. 2 (“Congress may by Law vest the Appointment of such inferior Officers, as they think proper . . . in the Heads of Departments.").

6. See Free Enter. Fund, 130 S. Ct. at 3163.

7. See id. 


\section{A BRIEF History of the DEPARTMENT HEAd Provision}

"The Constitution provides scant detail about federal personnel. It includes only a few references to officers, consuls, and ministers." ${ }^{8}$ With respect to the appointment of senior federal staff, the relevant portion of the Appointments Clause provides that "the Congress may by Law vest the Appointment of such inferior Officers, as they think proper, in the President alone, in the Courts of Law, or in the Heads of Departments." "9

Akhil Amar has described this Department Head provision as "a lastminute, housekeeping item" added at the very end of the Constitutional Convention in 1787.10 The original Appointments Clause offered at the convention stated only that " $[t]$ he President ... shall nominate and by and with the advice and consent of the Senate shall appoint ... all ... Officers of the U- S-."11 But the day before the proposed Constitution was finalized, Gouverneur Morris proposed additional language providing for appointments by the "heads of Departments," which was accepted with little debate. ${ }^{12}$ Thus, the Department Head provision represented a "very late" "concession to efficiency, since the appointment of inferior officers might be more trouble to the President and Senate than the extra procedural checks were worth.”13 Chief Justice John Marshall soon minimized the importance of the Department Head provision, explaining that it was only "an exception to the general provision" of presidential appointments added by "the framers of the constitution" to ensure that "they had provided for all cases of offices."

Many years later, Justice Antonin Scalia added a "unitary executive" spin to the provision, concluding that it was

8. DAVID E. LEWIS \& JeNNIFER L. SELIN, SOURCEBOOK OF UNITED STATES EXECUTIVE AGENCIES 66 (1st ed. 2012), available at http://www.vanderbilt.edu/csdi/ Sourcebook12.pdf (footnote omitted) (citing S. Comm. on Governmental Affairs, 96TH Cong., THE FEDERAl EXECUtive Establishment: Evolution AND TRENDS (Comm. Print 1980) (report authored by Ronald C. Moe of the Congressional Research Service); JoHN A. FAIRLIE, The NATiOnal Administration of the United StATES OF AMERica 55 (1922); Lloyd Milton Short, The Development of National Administrative Organization in the United States 15, 22, 26 (1923); W. F. Willoughby, An INTRODUCTION to the STUDY OF THE GOVERNMENT OF MODERN STATES 242 (1919)).

9. U.S. CONST. art. II, § 2, cl. 2.

10. See Akhil Reed Amar, Some Opinions on the Opinion Clause, 82 VA. L. REV. 647, 668 n.90 (1996).

11. See 2 The Records of the Federal Convention of 1787, at 498-99 (Max Farrand ed., 1966) (footnote omitted).

12. Id. at 627-28 (internal quotation marks omitted).

13. Hanah Metchis Volokh, The Two Appointments Clauses: Statutory Qualifications for Federal Officers, 10 U. PA. J. CONST. L. 745, 768 (2008).

14. United States v. Maurice, 26 F. Cas. 1211, 1213 (C.C.D. Va. 1823) (No. 15,747). 
perfectly obvious ... both from the relative brevity of the discussion this addition received, and from the content of that discussion, that it was intended merely to make clear ... that those officers appointed by the President with Senate approval could on their own appoint their subordinates, who would, of course, by chain of command still be under the direct control of the President. ${ }^{15}$

This idea is especially pertinent with respect to the chairmen of some multimember agencies, who are appointed directly by the President. ${ }^{16}$

Others have understood the provision as limiting either senatorial or executive powers. For example, Hanah Volokh has described the Department Head provision as a congressional check on the Presidentwho cannot directly nominate or remove inferior officers appointed by the heads of departments - as well as a means by which the President and House of Representatives could act to limit the Senate's potential abuse of its confirmation power over senior officials. ${ }^{17}$ Similarly, Justice Joseph Story viewed the Department Head provision as a grant of "discretionary power in congress" that "cannot well be questioned." 18

More recently, the Department of Justice has asserted that the Department Head provision "helps to ensure accountability for the quality of appointments and the operation of the Government" by authorizing "a limited number of publicly known and readily discernible sources of appointing authority, and also, ultimately, through the threat of impeachment” and removal by Congress, if department heads abuse their internal appointment authority. ${ }^{19}$ Thus, like the rest of the Appointments

15. Morrison v. Olson, 487 U.S. 654, 720-21 (1988) (Scalia, J., dissenting) (citation omitted).

16. See infra Appendix (noting, for example, unilateral presidential control over the designation of chairmen at the Federal Trade Commission, Nuclear Regulatory Commission, and Securities and Exchange Commission).

17. See Volokh, supra note 13, at 778; see also Presidential Appointment Efficiency and Streamlining Act of 2011, Pub. L. No. 112-166, 126 Stat. 1283 (2012) (eliminating the requirement of Senate confirmation for numerous inferior officer positions across the government, in recognition of the Senate's failure to approve nominations in a timely fashion); S. REP. No. 112-24, at 1 (2011), reprinted in 2012 U.S.C.C.A.N. 491 (explaining the intent of the 2011 Act).

18. 3 Joseph STORY, COMMENTARIES ON THE CONSTITUTION OF THE UNITED STATES $\S 1529$, at 382-84 (1833).

19. Memorandum from Steven G. Bradbury, Acting Assistant Attorney Gen., Office of Legal Counsel, to the Gen. Counsels of the Exec. Branch, Officers of the United States Within the Meaning of the Appointments Clause 3 (Apr. 16, 2007), available at http://www.justice.gov/olc/opiniondocs/appointmentsclausev10.pdf. 
Clause, the Department Head provision "reflects more than a 'frivolous' concern for 'etiquette or protocol.,",20

As a result, although the Department Head provision's phrase "as they think proper" "plainly gives Congress some discretion to allocate the appointment power," 21 "it is not 'within Congress's power to exempt federal instrumentalities from the Constitution's structural requirements.",22 Therefore, the Supreme Court has consistently held that "all officers of the United States are to be appointed in accordance with the Clause" and only properly appointed officers may exercise the enforcement, regulatory, and other administrative powers vested in a federal agency. ${ }^{23}$

\section{THE ORIGIN AND DEVELOPMENT OF MULTIMEMBER AGENCIES IN AMERICA}

The application of the Department Head provision remained completely uncontroversial during America's first century. Congress did not create very many federal agencies, and when it did, it exercised very little creativity in crafting their leadership structures. In short, essentially all agencies were led by individual secretaries or administrators operating alone. Thus, the "Head" of each "Department" was easy to identify-the Secretary of War was clearly the head of the War Department and could appoint inferior officers in that agency. Consequently, "the definition of 'Heads of Departments' has received much less attention” than other parts of the Appointments Clause. ${ }^{24}$

It was not until the 1880s that Congress began to seriously experiment with another model of agency leadership. In 1883, shortly after President Garfield's assassination by a disgruntled man seeking a patronage appointment, Congress passed the Pendleton Civil Service Reform Act. This Act created a new multimember agency - the three-member U.S. Civil Service Commission (USCSC), a collegial body that served outside of the President's direct chain of command and helped ensure that federal

20. Id. at 1 (quoting Buckley v. Valeo, 424 U.S. 1, 125 (1976) (per curiam)).

21. Memorandum from C. Kevin Marshall, Deputy Assistant Attorney Gen., Office of Legal Counsel, to the Gen. Counsel Office of Mgmt. \& Budget, Assignment of Certain Functions Related to Military Appointments 3 (July 28, 2005), available at http://www.justice.gov/olc/opiniondocs/militaryappointments.pdf.

22. Memorandum from Steven G. Bradbury, supra note 19, at 2 (quoting The Constitutional Separation of Powers Between the President \& Cong., 20 Op. O.L.C. 124, 148 n.70 (1996)).

23. Id. (quoting Buckley, 424 U.S. at 132) (internal quotation marks omitted).

24. Recent Case, Administrative Law-Appointments Clause-D.C. Circuit Holds that the SEC Chairman Is Not the "Head" of the SEC.-Free Enterprise Fund v. Public Co. Accounting Oversight Board, 537 F.3d 667 (D.C. Cir. 2008), cert. granted, 77 U.S.L.W. 3431 (U.S. May 18, 2009) (No. 08-861), 122 HARV. L. REV. 2267, 2267 (2009). 
employees would be selected on the basis of merit, without regard to politics. ${ }^{25}$ Four years later, apparently pleased with its prior work, Congress created the five-member Interstate Commerce Commission (ICC), ${ }^{26}$ which was the first truly "independent" regulatory commission-unlike the USCSC, the President could not remove its members without cause.

As Jay Bybee observed, the independent, multimember ICC

\begin{abstract}
was built on a new administrative model: Though it seemed to exercise executive power, the Commission, like Congress, was made collegial in order to offer its scientific expertise; like the judiciary, the Commission was made largely free of political pressure or reprisal. What the ICC offered [instead] was informed, dispassionate decisionmaking. ${ }^{27}$
\end{abstract}

Following the ICC's creation, the apparent success of this new multimember model apparently began to win over Congress, which soon created the Federal Reserve Board, Federal Trade Commission (FTC), Tariff Commission, Water Power Commission, Federal Radio Commission, Federal Power Commission, and Federal Home Loan Bank Board, all before President Franklin Roosevelt's election in $1932 .^{28}$

Fifty years after the creation of the USCSC, the Department of Justice (DOJ) was first to confront the new constitutional issue of appointments within these apparently multiheaded agencies. In 1933, Acting Attorney General J. Crawford Biggs recognized that "the three Commissioners, who constitute the [Civil Service] Commission, are the 'head of a Department' in the constitutional sense" and are therefore entitled to appoint a Chief Examiner and other "bureau officers, who are themselves the mere aids and subordinates of the heads of the departments." ${ }^{\text {,2 }}$ Thus, the DOJ has long recognized that the members of a commission or board could jointly act as head of a department and appoint inferior officers to serve under them.

25. See Pendleton Act, ch. 27, 22 Stat. 403 (1883) (codified as amended in scattered sections of 5 U.S.C.).

26. See Interstate Commerce Act of 1887, ch. 104, 24 Stat. 379, 383 (codified as amended in scattered sections of 49 U.S.C.).

27. Jay S. Bybee, Agency Expertise, ALJ Independence, and Administrative Courts: The Recent Changes in Louisiana's Administrative Procedure Act, 59 LA. L. REV. 431, 438 (1999) (footnoted omitted).

28. See id.

29. Auth. of Civil Serv. Comm'n To Appoint a Chief Exam'r, 37 Op. Att'y Gen. 227, 230, 231 (1933) (quoting United States v. Germaine, 99 U.S. 508, 511 (1878)) (internal quotation marks omitted). 
The first five years of President Roosevelt's New Deal quickly resulted in even more multimember agencies, such as the Federal Deposit Insurance Corporation, Farm Credit Administration, Federal Communications Commission (FCC), SEC, National Labor Relations Board, Bituminous Coal Commission, Federal Maritime Administration, and Civil Aeronautics Board. ${ }^{30}$ However, President Roosevelt soon grew frustrated with the actions of some Republican holdover members of the preexisting multimember agencies. His frustration only grew following a landmark Supreme Court decision, Humphrey's Executor v. United States, in which the Court blocked the President from firing a Republican FTC Commissioner over policy disagreements. ${ }^{31}$ Roosevelt then organized a special Committee on Administrative Management-the Brownlow Committee-which unsurprisingly concluded that "[f]or purposes of management, boards and commissions have turned out to be failures."32

As all presidents realized in the wake of Humphrey's Executor, multimember agencies necessarily "limit the President's influence by increasing the number of actors the President ... . must influence to direct agency policy." 33 At the same time, Congress learned the same lesson. It retains more influence over boards or commissions composed of multiple Senate-confirmed individuals-who may leak politically important agency information and otherwise compete to win congressional favor - than it has over administrators dependent on the President for their authority. Predictably, subsequent studies have shown that "[w]hen members of Congress fear the administrative influence of the current President ...., they are more likely to create independent commissions to implement their policies," whereas presidents conversely "see themselves as heads of the regulatory state and fight tooth and nail to resist congressional delegations to independent agencies.”34

After President Roosevelt's experience, subsequent presidents continued to fight to gain more control over multimember agency decisions-a key rationale motivating their very creation. Shortly after taking over from Roosevelt, President Truman began efforts "to centralize day-to-day direction and internal administration of [each multimember] agency in the

30. Bybee, supra note 27, at 438 .

31. See 295 U.S. 602, 618, 628-32 (1935).

32. PRESIDENT'S COMM. ON ADMIN. MGMT., REPORT OF THE COMMITTEE WITH STUdiES of AdMinistrative MANAGEMENT IN THE FEDERAL GOVERNMENT 32 (1937).

33. LEWIS \& SELIN, supra note 8, at 99.

34. Neal Devins \& David E. Lewis, Not-So Independent Agencies: Party Polarization and the Limits of Institutional Design, 88 B.U. L. REV. 459, 464, 466 (2008). 
chairman's hands in order to prevent .. . 'splintered management."'35 First, during Truman's Administration, a U.S. government task force conducted a comprehensive study of these multimember regulatory agencies on behalf of a congressionally mandated commission led by former President Herbert Hoover. ${ }^{36}$ The task force agreed with Roosevelt's Brownlow Committee that it was "very difficult for five or more commissioners to direct the work of the bureaus, or for the bureau chief to report to five or more masters" and therefore recommended, "the chairman should be specifically designated as the person responsible for administration within the commission." However, that same task force report advised that "the chairman's primary responsibility for administration should not supplant the ultimate authority of the entire commission on matters which are of major significance to the agency. For example, the commission should approve appointments of bureau or division chiefs, or major reorganizations of the staff."38

Shortly after receiving the Hoover Commission's task force report, President Truman convinced Congress to pass the Reorganization Act of 1949, which streamlined the process by which presidents could reorganize federal agencies. ${ }^{39}$ Most importantly, the Reorganization Act allowed presidents to reorganize multimember agencies by consolidating powers in the agencies' chairmen-who would generally be selected by the President himself-which led Senator Edwin Johnson, a fellow Democrat, to complain that Truman wanted "one-man agencies" subject to direct presidential control. ${ }^{40}$ However, reorganization remained-and remainssubject to congressional approval, and the Act contained one key provision regarding the identification and appointment of agency heads. That provision recognized that a "reorganization plan transmitted by the President [under] this section may provide that the head of an agency be

35. Marshall J. Breger \& Gary J. Edles, Established by Practice: The Theory and Operation of Independent Federal Agencies, 52 ADMIN. L. REV. 1111, 1168 (2000) (quoting Marvin H. BERnStein, Regulating Business by IndEPENDENT COMMISSION 173 (1955)).

36. See Commission on Organization of Executive Branch of the Government, Pub. L. No. 80-162, 61 Stat. 246 (1947).

37. COMm'n ON ORG. OF THE EXec. Branch of the Gov'T, COMMitTeE on IndePENDENT Regulatory COMmissions: A RePORT With ReCOMmENDATIONS 44, 46 (1949).

38. Id. at 47.

39. See Pub. L. No. 81-109, 63 Stat. 203 (codified as amended at 5 U.S.C. §§ 901-913 (2012)).

40. Daniel E. Ho, Measuring Agency Preferences: Experts, Voting, and the Power of Chairs, 59 DePaul L. Rev. 333, 359 (2010) (quoting Senate Kills ICC and FCC Revamping, WASH. Post, May 18, 1950, at A1) (internal quotation marks omitted). 
an individual or a commission or board with more than one member" and "[i]n the case of an appointment of the head of such an agency, ... [the appointment] shall be by the President, by and with the advice and consent of the Senate." 41 As explained in Part V of this Article, that statute's significance became clear with the Supreme Court's recent decision in Free Enterprise Fund. ${ }^{42}$

Eleven years after Congress passed the Reorganization Act, James M. Landis encouraged President-elect Kennedy to "make clear that the [presidentially selected] Chairman's authority extends to all administrative matters within the agency, including ... the appointment of ... personnel, except ... division heads whose appointment must be confirmed by a majority of the agency members." 43 And in fact, since the mid-twentieth century, there has been a notable increase in the number of politically appointed middle managers within federal agencies. ${ }^{44}$

In sum, "[o]ver the years a variety of presidentially inspired reorganization plans have transferred powers over [multimember] agencies' budget, hiring and priority-setting to the Chair, who is usually subject to appointment by the President," leading Paul Verkuil to question "whether centralizing power in the office of the Chair is not an attempt to make collegial agencies something they are not-single-headed agencies" that answer to the President on all important matters. ${ }^{45}$

\section{CHAIRMEN’s USE OF APPOINTMENT AUTHORITY WITHIN MULTIMEMBER AGENCIES}

Marshall Breger and Gary Edles concluded that without a doubt, "the chair of a multi-member agency is ordinarily its most dominant figure" because of the reforms authorized under the Reorganization Act. ${ }^{46}$ Similarly, Jay Bybee noted that when it comes to administrative agency design, "[s]tructure matters," 47 and in particular, for Daniel Ho, presidentially appointed "chairs matter" within multimember agencies, especially given their supervisory authority over staff within their agencies. ${ }^{48}$ Peter Strauss, a former general counsel in an independent,

\footnotetext{
41. 5 U.S.C. $\S 904$ (2012).

42. 130 S. Ct. 3138 (2010).

43. James M. LANDis, RePORt on Regulatory Agencies to the President-EleCt

44. LEWIS \& SELIN, supra note 8, at 67-68.

45. Paul R. Verkuil, The Purposes and Limits of Independent Agencies, 1988 DuKE L.J. 257, 265, 266 (footnote omitted).

46. Breger \& Edles, supra note 35, at 1164.

47. Bybee, supra note 27, at 431.

48. Ho, supra note 40 , at 358,360 .
} $85(1960)$ 
multimember agency-the Nuclear Regulatory Commission (NRC) agreed that vesting multimember agency chairmen with the ability to select senior agency staff mattered, especially to the extent that it naturally resulted in them "commanding staff loyalties," which helps the chairmen "dominate commission policymaking." 49 In such cases, "[t]he chairman usually gets what he wants."50

And notwithstanding the limits of a chairman's actual authority within a multimember agency, David Welborn noted that because of their power over personnel decisions and their ability "to name bureau chiefs who share the[ir] philosophy," chairmen are often perceived by agency employees as being "more potent sources of influence over staff activity than other members, individually or collectively."51 Thus, several agency staff members confided that their "Bureau directors will do anything the chairman wants" and that those senior officials "think of the chairman as the 'head of the agency,"' because they are at least partially "dependent on the good will of the chairman" for their offices. ${ }^{52}$

In fact, some agency chairmen have even "actively discouraged close relationships between [their fellow] commissioners and staff." 53 As a result, lower-level staff members seeking promotions are naturally "quite sensitive to the views of chairmen. . . ' 'Staff $\operatorname{tr}[y]$ to sniff the water concerning the chairman's preferences, and they will respond to them.",54 This works both ways, as agency staff members' receptivity to their chairmen allows the chairmen to maintain "numerous linkages with staff that allow them 'to keep in touch with what is going on' ... and that provide access to key determinations made at the staff level." 55 "Inevitably many of the working relationships between chairmen and staff members are such that other commissioners are not involved or even aware of them," 56 and the other commissioners or board members generally stay out of the personnel and staffing determinations, even though these

49. Peter L. Strauss, The Place of Agencies in Government: Separation of Powers and the Fourth Branch, 84 ColuM. L. REV. 573, 591 (1984).

50. David M. Welborn, Governance of Federal Regulatory Agencies 34 (1977) (internal quotations omitted).

51. Id. at 90, 94 (internal quotations omitted).

52. Id. at 94, 96 (internal quotations omitted).

53. Id. at 100

54. Id. at 91.

55. Id. at 94 .

56. Id. at 103 . 
decisions "may have a great impact on their agencies."57 For example, ongoing meddling in staff attorney hiring by one FTC Chairman was labeled "a major source of agency difficulties," and his immediate successor spent "a considerable portion of his time" reforming those recruitment policies and overseeing the replacement of over 750 staff members, leading to "[s]ignificant changes . .. in the manner in which the commission performed." 58

Although Welborn completed his study in the 1970s, there is little evidence that things have changed over time. For example, during only four years in office, one of President Clinton's FCC Chairmen hired approximately 200 new staff members-about ten percent of the agency's workforce at the time, including fifty percent of its policymaking staff. ${ }^{59}$ These appointments are "especially important" because these high-level staffers "shape critical regulatory choices in important and direct ways.,"60 In fact, another former FCC Commissioner agreed that "the FCC's chairman and a handful of staff — usually selected by the chair — can and usually do exercise nearly total control over that agency's basic policy agenda." ${ }^{\prime \prime}$

History suggests that this authority is not just a theoretical concern and that it has led to other troublesome abuses of chairmen's personnel powers in purportedly "collegial” multimember agencies. A good example would be the controversial reign of former FTC Chairman Paul Rand Dixon throughout the 1960s.

One of President Truman's Reorganization Plans, passed under the Reorganization Act, provided that the FTC Chairman could appoint almost all staff at the agency, with the standard exception for "the heads of major administrative units," whose chairman-initiated appointments had to be approved by the full Commission. ${ }^{62}$ Then-FTC Commissioner Philip Elman clashed with Chairman Dixon regarding the interpretation of this language. Elman argued that the "purpose of this provision, which applies to several of the independent regulatory agencies, was obviously to prevent the

57. Id. at 53.

58. Id. at 53-54.

59. See Reed E. Hundt, You Say You Want a Revolution: A Story of INFORMATION AGE POLITICS 69 (2000).

60. WeLBORN, supra note 50 , at 54 .

61. Glen O. Robinson, Independent Agencies: Form and Substance in Executive Prerogative, 1988 DuKE L.J. 238, 245 n.24; see also Breger \& Edles, supra note 35, at 1177-78 (noting that because chairmen are generally handpicked by the President, their "combination of political prestige and managerial authority" can give them "the power to dominate and control their agencies' agendas").

62. See Reorganization Plan No. 8 of 1950, 15 Fed. Reg. 3175 (Mar. 13 1950), reprinted in 64 Stat. 1264 (1950). 
agencies from being staffed by cronies, incompetents, or political hacks.”63 Elman complained of "all these [Dixon-appointed] directors and division chiefs, all these political hacks" occupying key positions, who were difficult to navigate around or remove. ${ }^{64}$ Elman's ally, Commissioner Mary Gardiner Jones, agreed and explained that

\begin{abstract}
we wanted to have some control over appointments of the senior staff, because that's where the Chairman has so much power and the Commissioners really have almost none. That's where all the decisions are made and that's how policy is made. The only role left [for individual Commissioners] is to write dissents and give speeches or talk to the press or whatever. But it's that control over appointments that to my mind was critical to influencing the Commission's direction. ${ }^{65}$
\end{abstract}

Chairman Dixon also recognized the value of this appointment power. In later testimony before Congress, while referring to the FTC Chairman's ability to control agency staff, he admitted that the "Chairman has got them all by the 'nape of the neck,' don't let anybody kid you that he doesn't." 66 In a private interview, Dixon also admitted that he

intended fully to see to it that the so-called Schedule $C$ jobs-these were the principal policy jobs of these bureaus - were going to be filled by Democrats. I was going to pick them, and they were going to be my people .... I'll tell you, a staff has a lot of influence upon these agencies. 67

Dixon noted that in "over eight years ... I hired several hundred people. I made some mistakes, but a surprisingly small number."68 Then, responding to Commissioner Elman's charges of cronyism, which included allegations that Chairman Dixon had illegally solicited political contributions from staff members that he had appointed, ${ }^{69}$ Dixon replied rather evasively

63. Philip Elman, Administrative Reform of the Federal Trade Commission, 59 GEO. L.J. 777, 857 (1971).

64. See Norman I. Silber, With All Deliberate Speed: The Life of Philip Elman 369 (2004).

65. Interview with Mary Gardiner Jones, FTC Comm’r 1964-1973 (Oct. 9 \& 24, 2003), available at http://www.ftc.gov/about-ftc/our-history/oral-histories/oral-histories/ oral-history-interview-mary-gardiner-jones.

66. Recent Efforts To Amend or Repeal the Robinson-Patman Act-Part 3: Hearings Before the Ad Hoc Subcomm. on Antitrust, the Robinson-Patman Act, and Related Matters of the H. Comm. on Small Bus., 94th Cong. 95 (1976) (statement of Paul Rand Dixon, Acting Chairman, FTC).

67. Interview with Paul Rand Dixon, FTC Chairman 1961-1969, in D.C. (Aug. 7, 1968), available at http://www.jfklibrary.org/Asset-Viewer/Archives/JFKOH-PRD-01.aspx.

68. Id.

69. SILBER, supra note 64, at 333. 
that "some of my new commissioners around here thin[k]—Elman, for instance, thinks that there's a lot of political bums around here, but he's an arrogant goddamned fellow anyway.... I'm not so damn, sure, though, that it wouldn't run better if it was a political haven.,70

Even though Elman was eventually able to cobble together a bare majority of the Commission to "call[] the shots on anything that called for commission action," he complained that the Chairman "was still running the commission, appointing staff people and so on. We made an effort to require him to obtain commission approval in certain personnel matters, but we didn't succeed." ${ }^{\text {71 }}$ In fact, despite a decisive 3-1 Commission vote to add sixty-five key staff positions to the list of "heads of major administrative units" whose appointment required Commission approval, Chairman Dixon — the sole dissenter — allegedly "announced that he would not carry out the Commission's mandate, which he deemed 'illegal.' True to his word, he [thereafter] avoided the thrust of the Commission's action by [unilaterally] making 'acting' appointments to fill vacancies" despite the absence of any clear legal authority to do so. ${ }^{72}$

As Commissioner Jones later explained, Chairman Dixon simply “wasn't going to allow" the Commission to seriously influence the selection of senior staff, and "[n]o Chairman is going to allow it because that's the way they impress their own personalities and beliefs on Commission policy and practice.... It probably was a losing battle, but it was critical because it was so hard to get past the staff."73

A subsequent outside study agreed that the FTC Chairman "can manipulate outcomes through his control of appointments .... While major appointments ... are subject to full commission approval, there is little doubt among the commissioners that the nominees are the chairman's people."74 Moreover, "[t]hat the bureau director should take his marching orders from the chairman rather than from the other commissioners is understandable. Without the support of the chairman, he would never have been chosen bureau director" because he would never have been nominated by the chairman. ${ }^{75}$

Somewhat disturbingly, former Commissioner Elman implied that after he challenged Chairman Dixon's authority, the Chairman retaliated by directing the agency's chief press officer, who was appointed by the

\footnotetext{
70. Interview with Paul Rand Dixon, supra note 67.

71. SILBER, supra note 64, at 362.

72. Elman, supra note 63, at 857-58 n.241 (internal quotation marks omitted).

73. Interview with Mary Gardiner Jones, supra note 65.

74. Robert A. Katzmann, Regulatory Bureaucracy: The Federal Trade COMMISSION AND ANTITRUST POLICY 87-88 (1980).

75. Id. at 88 .
} 
Chairman, not to distribute copies of Elman's speeches to the press, despite his commonly understood duty to do so. ${ }^{76}$ And when the next chairman arrived at the FTC, he used his considerable appointment power "to reorganize the commission," which "enabled [him] to move a lot of staff people into other jobs, perhaps not as cushy, but he didn't fire anybody; he just moved them aside."77

These battles and displays of chairman power over agency staff were certainly not unique to the FTC and have continued at other agencies up to the present. For example, with respect to the use or misuse of the chairman's authority over an agency's press office, a 2011 congressional inquiry charged that the NRC's Director of Public Affairs-directly appointed and controlled by the Chairman-had "emailed reporters urging them to read an outside report that denigrated the [other] four commissioners and criticized them for not supporting [the Chairman's] proposals."78 Likewise, an Inspector General report concluded that, similar to Chairman Dixon, former NRC Chairman Gregory Jaczko sometimes ignored the Commission majority's expressed will and "instructed the Secretary of the Commission not to follow the consensus approach of the [other] four Commissioners." ${ }^{\prime 79}$ The NRC also went over six months with a chairman-appointed "Acting” General Counsel after then-Chairman Jaczko apparently refused to nominate a permanent General Counsel who was

76. See SILBER, supra note 64, at 331.

77. Id. at 369 .

78. Letter from House Comm. on Energy and Commerce to Gregory B. Jaczko, Chairman of the Nuclear Regulatory Comm'n 4 (Apr. 27, 2012), available at http://energy commerce.house.gov/sites/republicans.energycommerce.house.gov/files/letters/20120427NR C.pdf.

79. See OfFice of the InSPector Gen., U.S. NuClear Regulatory Comm’N, InVEstigative Report: Possible Violations of the REORGANiZATION Plan No. 1 of 1980 AND NRC'S INTERNAL COMMISSION PROCEDURES BY NRC CHAIRMAN 79 (2012), available at http://energycommerce.house.gov/sites/republicans.energycommerce.house.gov/files/Hearings /Joint/20120724_EE_EP/HMTG-112-HHRG-IF18-IF03-20120724-SD002.pdf; see also id. at 85, 86 ("Commissioner Ostendorff expressed his view that the Chairman attempts to conduct business as a single administrator rather than the head of a Commission, and seeks to override majorities of Commissioners by dint of his position as Chairman. ... One executive ... recalled that the Chairman [once said] 'You're on my team. ... I work with the Commission. You shouldn't work with the Commission.,"); id. at 94 (stating that the Chairman instructed senior officials reporting to him that they must work through him and not provide other Commissioners with information). 
acceptable to the Commission majority and instead left that task to the next chairman. ${ }^{80}$

Similarly, a 2008 congressional investigation noted that recent former FCC Chairman Kevin Martin had, like the former FTC Chairmen, used and abused his executive and supervisory authorities over agency staff to immediately and unilaterally reassign or "demote" a number of senior agency officials without technically removing them or reducing their pay, which would have required the approval of the Commission majority. ${ }^{.1}$ This obvious loophole exists in almost all multimember agencies and drastically weakens various multimember commissions' and boards' supposedly shared authority over the placement of inferior officers, leaving the agencies ripe for domination and agenda control by chairmen, including those who fail to command a majority in regular policymaking endeavors.

On the other hand, this is not to say that chairmen always come out victorious in their attempts to completely dominate the selection of agency staff. For example, in 1999, the Chairman of the Chemical Safety and Hazard Investigation Board announced that hiring personnel was, in his opinion, an administrative function within his sole authority at the agency ${ }^{82}$ despite legislative history that undermined his claim. However, the board resisted his power grab-with the support of some influential Senators and the DOJ's Office of Legal Counsel—and the Chairman eventually backed down. ${ }^{83}$

Perhaps unsurprisingly, a recent study by Daniel Ho concluded that historically, these attempted power grabs are "the rule, not the exception" in multimember agencies. ${ }^{84}$ Clearly, this is not ideal and cannot be the most legally and politically sensible or viable structure for organizing a federal agency.

As a result, Congress and sitting members of multimember agencies have continually debated the consolidation of multimember agency authority in presidentially selected chairmen, and those chairmen have often eagerly supported presidential efforts to increase their power. As early as 1954, one commissioner alleged that some politicians sought to transform

80. See Press Release, Office of Pub. Affairs, U.S. Nuclear Regulatory Comm'n, Margaret M. Doane Named NRC General Counsel (Oct. 11, 2012), available at http:// www.nrc.gov/reading-rm/doc-collections/news/2012/12-111.pdf (noting that the prior general counsel retired on March 31, 2012).

81. See Majority StAFF OF House Comm. On ENERgy \& CoMmerCe, 110th Cong., DECEPTION AND DisTRUST: THE FEDERAL COMMUNICATIONS COMMISSION UNDER CHAIRMAN KEVIN J. MARTIN 20 (2008).

82. Guy Gugliotta, Chemical Hazards Board and Chief a Volatile Mix, WASH. Post, Nov. 24, 1999, at A21.

83. See Breger \& Edles, supra note 35, at 1179-80.

84. Ho, supra note 40, at 360. 
multimember agencies from panels of essentially equal partners to entities led by "a Chairman and four junior-grade Commissioners" who would essentially function only as advisers to the chairman. ${ }^{85}$ These charges are not necessarily inaccurate.

In the 1970s, one agency chairman told David Welborn that "[a]ll commissioners are equal, but the chairman is more equal than others." 86 Likewise, recent Chairman Neil McPhie of the Merit Systems Protection Board openly expressed his desire for even more power at his agency, announcing his view that "as chairman, he occupies 'a position of responsibility that is superior and not co-equal to that of the other two Board members,' and that he is [or should be] 'the head of the agency.",87 In essence, Chairman McPhie was asking Congress to convert his agency into the single-administrator model, as some scholars ${ }^{88}$ and even commissioners $^{89}$ have recommended in the past. In fact, going back to Alexander Hamilton, many have inveighed against the evils of a "plurality in the executive" with respect to "the appointment to offices." 90

85. S. 3323 and H.R. 8862, To Amend the Atomic Energy Act of 1946: Hearings Before the J. Comm. on Atomic Energy, 83d Cong. 851-52 (1954) (statement of Eugene M. Zuckert, Comm'r, Atomic Energy Comm'n) (criticizing proposals supported by the Atomic Energy Commission's Chairman to describe the Chairman as that agency's "principal officer").

86. WELBORN, supra note 50, at 91 (internal quotation marks omitted).

87. Ensuring a Merit-Based Employment System: An Examination of the Merit Systems Protection Board and the Office of Special Counsel: Hearing Before the Subcomm. on Fed. Workforce Postal Serv., and the D.C. of the H. Comm. on Oversight and Gov't Reform, 110th Cong. 60 (2007) [hereinafter Ensuring a Merit-Based Employment System] (statement of Morton Rosenberg, Senior Analyst, Cong. Research Serv.) (quoting Safeguarding the Merit Systems Principles: A Review of the Merit Systems Protection Board and the Office of Special Counsel: Hearing Before the Oversight of Gov't Mgmt., the Fed. Workforce, \& the Dist. D.C. Subcomm. of the S. Comm. on Homeland Sec. \& Governmental Affairs, 110th Cong. 101, 103 (2007) (statement of Neil McPhie, Chairman, U.S. Merit Sys. Prot. Bd.)).

88. See, e.g., John G. KeMENY ET Al., RePORT OF THE PRESIDENT's COMMISSION ON THE ACCIDENT AT THREE MILE IsLAND 21-22 (1979) (recommending replacing the NRC's "highly compartmentalized" "huge bureaucracy under the commissioners" with a more streamlined agency "headed by a single administrator, who is in every sense chief executive officer"), available at http://www.threemileisland.org/downloads/188.pdf.

89. See, e.g., Reorganization Plan No. 1 of 1980 (Nuclear Regulatory Commission): Hearing Before a Subcomm. of the H. Comm. on Gov't Operations, 96th Cong. 39 (1980) [hereinafter Reorganization Plan No. 1 of 1980] (statement of John F. Ahearne, Chairman, Nuclear Regulatory Comm'n).

90. The Federalist No. 70, at 474, 477 (Alexander Hamilton) (Jacob E. Cooke ed., 1961) (concerning the executive department). 
As former Representative Frank Horton noted in 1980, "One school of thought wants to eliminate the Commission completely and replace it with a single administrator. This does, of course, have great appeal from an economic and efficiency viewpoint." ${ }^{\text {"1 }}$ On the other hand, Representative Horton admitted that with respect to multimember regulatory agencies, "it might be best to have many viewpoints with a diversity of opinion. ... [I]nherent in a collegiality body. ... . [F]or the very important duties of [setting] policy and rulemaking." President Carter's Office of Management and Budget agreed that singleadministrator rule can "narrow the diversity of viewpoints and reduce safeguards against unwise decisions." 93 Moreover, he noted that Congress agreed that a collegial structure was preferable and had chosen to form multimember agencies rather than continuing the historical model of single-administrator agencies. ${ }^{94}$

Even more recently, at least one branch of Congress has tried to swing the pendulum back toward the old multimember format, at least with respect to one powerful new agency. Since 2010, the Republican-controlled House of Representatives has repeatedly sought to change the leadership structure of the new Consumer Financial Protection Bureau from a single director to a commission, "like ... other federal agencies." 95 The ideal bureau, according to the House, would include a chairman who "would fulfill the executive and administrative functions of [the agency but whose] discretion would be bounded by policies set by the whole Commission." ${ }^{96}$ Such a structure would "promote sound, stable policymaking" and

ensure[] that multiple perspectives are brought to bear on decisions ... , and that different points of view will be considered .... [T] more stability, ensures continuity in knowledge, provides for the continuous presence of experienced members at all times, and prevents gaps in agency effectiveness. Moreover, a commission structure promotes predictability in rulemaking by preventing a new [single administrator] from unilaterally and abruptly reversing the decisions made by a previous [single administrator]. ${ }^{97}$

91. Reorganization Plan No. 1 of 1980, supra note 89, at 17 (statement of Rep. Frank Horton).

92. Id.

93. Id. at 21 (statement of Harrison Wellford, Executive Associate Director, Office of Mgmt. \& Budget).

94. Id. at 33.

95. See H.R. REP. No. 112-107, at 4-5 (2011).

96. Id. at 5 .

97. Id. 
Representative Spencer Bachus, the Chairman of the House Committee on Financial Services, concluded that " $[t]$ his is a structure that has worked well for nearly every other regulatory body in this country."

Yet despite the political battles, there have been few constitutional arguments about the competing models of internal agency appointments. After the initial wave of agency reorganizations in the 1950s and 1960s, the General Accounting Office-part of Congress ${ }^{99}$ _advised the ICC that it could not require the agency's bureau chiefs to report directly to commissioners other than the chairman, in light of the chairman's executive and administrative authorities. ${ }^{100}$ But much more recently, the Congressional Research Service concluded that it "is well established that chairpersons are not the heads of Federal collegial bodies .... [T] he chairman of no ... multi-member independent agency is in any constitutional or legal sense the 'head' of such a collegial body."101

Similarly, since its initial opinions concerning the USCSC's joint appointment of inferior officers, the DOJ has issued several "opinions addressing governance issues raised by multi-member boards and commissions" and has "repeatedly recognized that basic and well-established principles of corporate common law make clear 'that the basic premise governing deliberative bodies is that the majority rules.",102 Thus, although many multimember agency chairmen are described as their agency's "chief executive," 103 it is clear that "CEOs and presidents of corporations, as a matter of corporate common law, are 'subordinate in legal authority'

98. Press Release, House Comm. on Fin. Servs., Chairman Bachus Comments on Legal Challenge to Dodd-Frank Act (June 21, 2012), available at http://financial services. house.gov/News/DocumentSingle.aspx?DocumentID=300403.

99. See LEWIS \& SELIN, supra note 8, at 9.

100. Letter from Elmer B. Staats, Comptroller Gen., U.S. Gen. Accounting Office, to George M. Stafford, Chairman, Interstate Commerce Comm’n (July 25, 1974).

101. Ensuring a Merit-Based Employment System, supra note 87, at 60, 86.

102. Div. of Powers \& Responsibilities Between the Chairperson of the Chem. Safety \& Hazard Investigation Bd. \& the Bd. as a Whole, 24 Op. O.L.C. 102, 105 (2000) (quoting Letter from Larry L. Sims, Deputy Assistant Attorney Gen., Office of Legal Counsel, to Mason H. Rose V, Chairperson, U.S. Architectural \& Transp. Barriers Compliance Bd. 2 (Sept. 17, 1981)).

103. See Recent Case, supra note 24, at 2272 (quoting The Investor's Advocate: How the SEC Protects Investors, Maintains Market Integrity, and Facilitates Capital Formation, U.S. SEC. \& EXCHANGE COMMISSION, http://www.sec.gov/about/whatwedo.shtml\#.Uypf OvldUYI (last visited Apr. 25, 2014)) (internal quotation marks omitted). 
to their corporations' boards of directors, ${ }^{, 104}$ and thus these chairmen presumably are-or should be-subordinate to the full commission or board.

However, the Supreme Court never directly confronted the thorny issue of appointment authorities at multimember agencies until 2010, when it considered Free Enterprise Fund v. Public Co. Accounting Oversight Board. ${ }^{105}$

\section{FreE ENTERPRISE Fund V. PUBLIC Co. ACCOUNTING OVERSIGHT BOARD}

In 2006, the nonprofit Free Enterprise Fund and one of its members, a Nevada accounting firm, brought a lawsuit in the U.S. District Court for the District of Columbia, alleging, among other things, that the members of the Public Company Accounting Oversight Board - created by the Sarbanes-Oxley Act of 2002-had been unconstitutionally appointed by the SEC, which had approved nominations initiated by the Chairman of the SEC. ${ }^{106}$ The Free Enterprise Fund argued that a number of circumstances made these appointments unconstitutional, but for the purposes of this Article, its most pertinent claim alleged that the Commission acting collectively was not the head of the SEC for purposes of the Appointments Clause and therefore could not appoint, or approve the appointment of, inferior officers, such as the board members. ${ }^{107}$ Instead, the fund argued that the SEC's Chairman must have sole authority over such appointments. ${ }^{108}$

Although the district court did not reach the merits of this challenge, the U.S. Court of Appeals for the D.C. Circuit did. The Court of Appeals split on other questions, but the panel unanimously concluded that the Commission-at-large, rather than the Chairman of the agency, properly functioned as the head of the SEC for purposes of the Appointments Clause. $^{109}$

Some scholars quickly criticized this decision, arguing that "vesting the appointment power in the multimember Commission violates the

104. Div. of Powers \& Responsibilities Between the Chairperson of the Chem. Safety \& Hazard Investigation Bd. \& the Bd. as a Whole, supra note 102, at 107 (quoting WiLLIAM J. Grange, Corporation Law for OfFicers and Directors: A Guide to Correct PROCEDURE 450 (1935)).

105. 130 S. Ct. 3138 (2010).

106. See Free Enter. Fund v. Pub. Co. Accounting Oversight Bd., 537 F.3d 667, 669-70 (D.C. Cir. 2008), rev’d, 130 S. Ct. 3138 (2010).

107. Id. at 672 .

108. See id. at 678 .

109. See id. at 677-78; id. at 712 n.24 (Kavanaugh, J., dissenting on other grounds). 
Appointment[s] Clause's intent by not reserving the appointment power in the SEC's most politically accountable actor, the Chairman." 110 In addition, they argued that a chairman's authority over all executive and administrative functions makes the chairman more than "simply a commissioner with extra duties." executive powers may mean that the chairman "exerts far more control than ... one vote would seem to indicate," through administrative authority over "key personnel, internal organization, and the expenditure of funds."112 Unsurprisingly, the Free Enterprise Fund promptly appealed to the Supreme Court, making some of these same arguments. ${ }^{113}$

The Solicitor General's brief on behalf of the United States pointed out that "[a]s a body, the Commissioners exercise the same kind of final authority that is vested in the single 'Head' of a traditional Cabinet department, and the statutory provisions granting rulemaking, investigative, and adjudicative authority uniformly vest that authority in 'the Commission,' rather than its Chairman." ${ }^{\text {"114 }}$ Thus, the Solicitor General argued that "[t]reating the Commissioners as the SEC's 'Head' . . . is much more natural than saying that the SEC has no 'Head,' or that its 'Head' is a person in whom Congress has not vested the agency's final decisionmaking authority." 115

The Supreme Court agreed with the D.C. Circuit and Solicitor General on this point. Specifically, the Court held that the joint Commission was the SEC's head for three reasons:

1. “The Commission's [rulemaking, adjudicatory, and investigatory] powers ... are generally vested in the Commissioners jointly, not the Chairman alone.” 116

2. "[T]he Chairman ... exercises administrative and executive functions subject to the full Commission's policies."

110. See, e.g., Recent Case, supra note 24, at 2270.

111. See id. at 2271-72.

112. Id. at 2272 (quoting SEC v. Blinder, Robinson \& Co., 855 F.2d 677, 681 (10th Cir. 1988)) (internal quotation marks omitted).

113. See Petition for Writ of Certiorari at 38, Free Enter. Fund v. Pub. Co. Accounting Oversight Bd., 130 S. Ct. 3138 (2010) (No. 08-861).

114. Brief for the United States at 39, Free Enter. Fund, 130 S. Ct. 3138.

115. Id. at 40.

116. Free Enter. Fund, 130 S. Ct. at 3163.

117. Id. 
3. "The Chairman is also appointed from among the Commissioners by the President alone, which means that he cannot be regarded as 'the head of an agency' for purposes of the Reorganization Act," which applies to agencies operating under a "Reorganization Plan," such as the SEC, pursuant to that Act, 5 U.S.C. $§ 901$ et seq. ${ }^{118}$

The Court also cited historical decisions from all three branches sanctioning this determination. ${ }^{119}$

The Free Enterprise Fund had argued that such a conclusion would inevitably mean that the appointment of all of the SEC's inferior officers were invalid because all of the agency's officers are appointed by the Chairman, with the approval of the Commission required for the "heads of major ... administrative units."120 However, the Court disagreed and noted that its decision did not "invalidate numerous appointments made directly by the Chairman" because "their appointment is still made 'subject to the approval of the Commission,"” and based on past "precedents that petitioners do not ask us to revisit," "the department head's approval satisfies the Appointments Clause."121 With that, the Court's brief discussion was complete. But what are its implications for the many multimember agencies currently in existence?

\section{WHO ARE THE “INFERIOR OFFICERS” AT MULTIMEMBER AGENCIES?}

Some of the earliest and most influential constitutional commentators were befuddled regarding the scope of "inferior Officers" under the Appointments Clause. As William Rawle wrote in 1829, "The term 'inferior' is somewhat vague, and it is perhaps left to congress to determine how to apply it."122 Likewise, Justice Joseph Story recognized that "there does not seem to have been any exact line drawn, who are, and who are not, to be deemed inferior officers in the sense of the constitution.",123

\footnotetext{
118. Id.

119. Id. at 3164 (citing Classification Act of 1923, ch. 265, § 2, 42 Stat. 1488; Freytag v. Comm'r, 501 U.S. 868, 918 (1991) (Scalia, J., concurring in part and concurring in judgment)); Auth. of Civil Serv. Comm'n To Appoint a Chief Exam'r, 37 Op. Att'y Gen. 227, 231 (1933).

120. Free Enter. Fund, 130 S. Ct. at 3163 n.13 (internal quotation marks omitted).

121. Id. (quoting Reorganization Plan No. 10 of $1950 \S 1$ (b)(2), 3 C.F.R. $\S 1006$, reprinted in 5 U.S.C. app. at 623 (2012)).

122. William Rawle, A View of the Constitution of the United States of AMERICA 164 (photo. reprint 2003) (2d ed., Philadelphia, Philip H. Nicklin 1829).

123. STORY, supra note $18, \S 1530$, at 386.
} 
Over 100 years later, the 1949 congressional task force report simply advised that each full board or commission retain ultimate authority for the appointment of "bureau or division chiefs." 124 The Landis report to President-elect Kennedy agreed. ${ }^{125}$ More recently, the DOJ has concluded that "Officers" as described in the Appointments Clause may include anyone occupying a continuing position that is "invested by legal authority with a portion of the sovereign powers of the federal Government."

The "invested by legal authority" criterion is simple enough to understand-official authority must be lawfully delegated. As for "sovereign powers," the DOJ studied the relevant case law and concluded that these include the ability "to bind third parties, or the Government itself, for the public benefit” by engaging in diplomatic or military functions; controlling public funds; signing contracts or other legal instruments on behalf of the government; or administering, executing, or interpreting the law. ${ }^{127}$ Moreover, these powers even include the authority to plan and carry out a limited number of commemorative events on behalf of the federal government. ${ }^{128}$

Similarly, Kent Barnett recently surveyed the relevant Supreme Court case law and reported that the Court has defined an "Officer of the United States" as

"any appointee exercising significant authority pursuant to the laws of the United States" .... The significance of one's authority "marks the line between officer and nonofficer." [D]istrict court clerks, thousands of clerks in the executive departments, an assistant surgeon, and even a cadet-engineer have all been deemed officers ... . . Indeed, the Court has indicated that even if certain of an individual's duties are ministerial, the individual's discretionary duties will control. ${ }^{129}$

124. See COMM'N ON ORG. OF THE EXEC. BRANCH OF THE Gov'T, supra note 37, at 47.

125. See supra text accompanying note 43.

126. Memorandum from Steven G. Bradbury, supra note 19, at 1.

127. See id. at 12-15.

128. See, e.g., Memorandum from Martin S. Lederman, Deputy Assistant Attorney Gen., Office of Legal Counsel, to the Acting Assistant Attorney Gen. for the Office of Legislative Affairs, Constitutionality of the Ronald Reagan Centennial Commission Act of 2009, at 1 (Apr. 21, 2009), available at http://www.justice.gov/olc/opiniondocs/reagan centennialcommission.pdf.

129. Kent Barnett, The Consumer Financial Protection Bureau's Appointment with Trouble, 60 AM. U. L. REV. 1459, 1467-68 (2011) (footnotes omitted) (quoting Edmond v. United States, 520 U.S. 651, 662 (1997); Buckley v. Valeo, 424 U.S. 1, 126 (1976) (per curiam)) (citing Free Enter. Fund v. Pub. Co. Accounting Oversight Bd., 130 S. Ct. 
Unfortunately, the Court, like the DOJ, has thus far set forth vague, sweeping tests devoid of much specificity. Whether one exercises "significant authority" or "sovereign powers" is usually not clear. So who are the inferior officers of the United States?

For the more limited purposes of this Article, it is easier to simply look to those bureau or division chiefs who should undoubtedly qualify, as noted by the 1948 task force and 1960 report to President-elect Kennedy. ${ }^{130}$ One easy "cheat sheet" method for identifying these inferior officers relies upon The United States Government Manual, a somewhat obscure executive branch publication that by regulation annually lists all "officials heading major operating units" within agencies. ${ }^{131}$

Because the Supreme Court has concluded that inferior officers "are officers whose work is directed and supervised at some level by others who were appointed by Presidential nomination with the advice and consent of the Senate"132 and all of these bureau and division heads are supervised by their presidentially appointed and Senate-confirmed agency heads, they should all be inferior officers under the Appointments Clause and its Department Head provision. Therefore, they are ideal subjects for the purpose of studying the appointment process at multimember agencies.

\section{FREE ENTERPRISE FUND AND CURRENT MULTIMEMBER AGENCY APPOINTMENTS}

As the attached Appendix demonstrates, there are many division chiefs, bureau heads, and other inferior officers at multimember agencies who are appointed solely by the chairman of a multimember board or commission.

For example, although certain named officers are approved by the full Consumer Product Safety Commission after nomination by the Chairman, ${ }^{133}$ that agency's Chairman appoints any "other officers.","134 Likewise, at the Export-Import Bank, the Board appoints most officers, ${ }^{135}$ but the President of the Bank-equivalent to its Chairman-directly appoints a senior vice president who manages the Small Business Division. ${ }^{136}$ Similarly, the Chairman of the NRC unilaterally appoints

3138, 3179 (2010) (Breyer, J., dissenting); Freytag v. Comm’r, 501 U.S. 868, 881-82 (1991)).

130. See supra text accompanying notes 124-25.

131. 1 C.F.R. $\S 9.2(a)(3)(2013)$.

132. Edmond, 520 U.S. at 663.

133. 15 U.S.C. § 2053(g)(1) (2006).

134. Id. § 2053(g)(2).

135. See 12 U.S.C. § 635A(c)(7) (2012).

136. Id. § 635A(f)(2). 
the directors of that agency's Office of Congressional Relations and Office of Public Affairs, ${ }^{137}$ even though the Commission must approve the Chairman's nominees to head a number of other offices. ${ }^{138}$

Strangely, the NRC Chairman is also "responsible for ... appointing and removing without any further action by the Commission, all [other] officers" but by statute must delegate this responsibility to the agency's Executive Director for Operations, an inferior officer appointed and supervised by the Commission. ${ }^{139}$ As a result, the Executive Director for Operations appoints and supervises a number of inferior officers, including three Deputy Executive Directors. All of these Deputy Executive Directors supervise agency office directors, and two of them supervise the performance of officers whose appointments are confirmed by the Commission, such as the Directors of the Offices of Nuclear Reactor Regulation and Nuclear Material Safety and Safeguards. ${ }^{140}$ Unsurprisingly, this very legally dubious arrangement appears to be unique within the federal government.

The situation is much more straightforward at the Equal Employment Opportunity Commission, ${ }^{141}$ Federal Energy Regulatory Commission, ${ }^{142}$ Merit Systems Protection Board, ${ }^{143}$ National Transportation Safety Board, ${ }^{144}$ and Occupational Safety and Health Review Commission, ${ }^{145}$ where the chairmen simply appoint and remove all officers. Similarly, the Chairman of the Federal Maritime Commission (FMC) appoints all office directors at that agency "but only after consultation with the other Commissioners," who have no apparent authority to approve or disapprove these appointments. ${ }^{146}$ And finally, the Chairman of the International Trade Commission (ITC) has statutory authority to appoint all agency

137. Reorganization Plan No. 1 of 1980 § 2(a), 45 Fed. Reg. 40,561 (June 16, 1980), reprinted in 5 U.S.C. app. at 737 (2012).

138. See id. §1(b).

139. Id. § 2(b).

140. See id. §§ 1(b)(2), 2(b); see also U.S. Nuclear Regulatory Commission: The Commission, U.S. NuCLEAR REG. COMMISSION (Aug. 25, 2013), http://www.nrc.gov/aboutnrc/organization/nrcorg.pdf (outlining the organization).

141. 42 U.S.C. § 2000e-4(a) (2006).

142. Id. § 7171(c).

143. 5 U.S.C. $\S 1204(\mathrm{j})(2012)$.

144. 49 U.S.C. § 1111(e)(1), (h) (2006).

145. 29 U.S.C. $\$ 661(\mathrm{e})(2006)$.

146. 46 U.S.C. § 301(c)(3)(A)(ii) (2006); see also id. § 301(c)(3)(A)(i) (providing the Chairman of the Federal Maritime Commission with authority to appoint all other officers at the agency). 
officers unless a majority of the Commission votes to disapprove those appointments. ${ }^{147}$ This arrangement effectively gives the Chairman a tiebreaking power - a 1-1 or 2-2 vote results in the appointment of an officer nominated by the Chairman. On the other hand, the ITC Chairman may remove officers only when a majority of the Commission affirmatively votes to approve such action. ${ }^{148}$

In light of the Supreme Court's decision in Free Enterprise Fund, what do we make of all these appointments that are currently made without full board or commission approval? Who are the heads of these agencies for Appointments Clause purposes?

Applying the Court's criteria, in each case, the agencies' respective boards or commissions - all properly consisting of presidential appointees ${ }^{149}$ —hold all adjudicatory, rulemaking, and investigatory authorities. $^{150}$ In addition, recall that the default position, as recognized by the DOJ, is that the respective boards are the highest authorities in multimember agencies. ${ }^{151}$

Furthermore, none of the relevant statutes state that the respective chairmen are not bound by their full boards' or commissions' policies, and the chairmen of the Consumer Product Safety Commission, ${ }^{152}$ FMC, ${ }^{153}$ NRC, ${ }^{154}$ and National Transportation Safety Board ${ }^{155}$ are explicitly required to follow the general policies set by their respective boards or commissions. Moreover, the NRC is governed by a Reorganization Plan, ${ }^{156}$ so under the Reorganization Act, the "head of [that] agency"157 cannot be its Chairman, who is selected by the President alone. ${ }^{158}$

The only alternative theory justifying the current arrangement requires a conclusion that multimember agencies have multiple heads for different purposes-perhaps the chairman would act as the head when appointing

147. 19 U.S.C. § 1331(a)(1) (2006).

148. Id. § 1331(a)(2)(A).

149. See Printz v. United States, 521 U.S. 898, 922 (1997) (concluding that "'the Heads of Departments' [must be] themselves Presidential appointees” (quoting U.S. ConsT. art II, § 2)).

150. See infra Appendix (listing authorities for each multimember agency).

151. See supra notes 102, 104 and accompanying text.

152. 15 U.S.C. § 2053(f)(2) (2006).

153. 46 U.S.C. § 301(c)(2) (2006).

154. Reorganization Plan No. 1 of 1980 § 2(c), 45 Fed. Reg. 40,563 (June 16, 1980), reprinted in 5 U.S.C. app. at 737-38 (2012).

155. $\quad 49$ U.S.C. $\S 1111(\mathrm{e})(2006)$.

156. See Reorganization Plan No. 1 of $1980 § 1$ 1(a), 45 Fed. Reg. 40,561 (June 16, 1980), reprinted in 5 U.S.C. app. at 737.

157. See 5 U.S.C. § 904 (2012); see also Free Enter. Fund v. Public Co. Accounting Oversight Bd., 130 S. Ct. 3138, 3163 (2010) (discussing application of the Reorganization Act).

158. See 42 U.S.C. $\S 5841(a)(1)(2006)$. 
some inferior officers, and the board or commission would act as the head when appointing others. But it would be difficult to imagine how such a bizarre, hydra-like arrangement could effectively function. For example, how would anyone determine who was the head for the purposes of various statutes? And who would ultimately command agency staff? Whose orders would the staff and regulated entities follow in the event of a conflictthe chairman or the board? Even the Free Enterprise Fund did not anticipate such a holding, arguing that there should be only "one" head-the chairman, in its opinion. ${ }^{159}$ Thus, the Supreme Court's recently announced criteria clearly point to the conclusion that the constitutional heads of these multimember agencies, as currently structured, cannot be their chairmen but must be their full boards or commissions, acting jointly.

\section{WHAT ABOUT THE “APPROBATION RULE” AND REMOVAL POWERS?}

One last defense of some mixed, hydra-like appointment authorities might be the Supreme Court's old "approbation rule," which has been interpreted to "permit[] a department head to approve a subordinate's appointment of an inferior officer," although it "applies [only] to situations in which the statute expressly requires the department head to approve the appointment." 160 This rule is followed in many multimember agency appointments, by providing that the full board or commission must vote to approve the chairman's "nominees" for those positions. ${ }^{161}$

Some scholars have argued that these longstanding practices of the executive and legislative branches deserve to be accorded some interpretive deference when considering the limits of the Appointments Clause. ${ }^{162}$ This position would hold that the Free Enterprise Fund Court cannot have intended, in such a brief discussion toward the end of the opinion, to implicitly order Congress to rewrite scores of statutory appointment provisions that have been in place for decades.

159. Brief for Petitioners at 60, Free Enter. Fund, 130 S. Ct. 3138.

160. Barnett, supra note 129, at 1481 n.159 (internal quotation marks omitted) (citing United States v. Smith, 124 U.S. 525, 532-33 (1888); United States v. Hartwell, 73 U.S. (6 Wall.) 385, 393-94 (1868)).

161. See infra Appendix.

162. See, e.g., Note, Congressional Restrictions on the President's Appointment Power and the Role of Longstanding Practice in Constitutional Interpretation, 120 HARV. L. REV. 1914, 1927-35 (2007). 
Although this argument has the advantages of "stability and practicality," Hanah Volokh has argued sensibly that "a long history of violating the Constitution does not make continuing violations acceptable. Acquiescence in a practice believed to be unconstitutional can only be reasonable if there is a good argument that the practice is in fact constitutional."163

Although the Free Enterprise Fund decision cited the approbation rule and its foundation in much earlier cases from the nineteenth century, the Court obliquely questioned the validity of this theory by simply noting that these old cases were "precedents that petitioners do not ask us to revisit,"164 rather than offering any sort of reaffirmation or endorsement of the rule.

In fact, in its reply brief before the Court, the Free Enterprise Fund attempted to brush aside the significance of the approbation rule by simply pointing out that "as Senate confirmation hearings demonstrate, approval is fundamentally different than appointment, and results in different officers being selected." "65 The fund was undoubtedly correct.

The Senate would surely confirm different officers if it could both nominate and approve them, rather than simply approving presidential nominees. ${ }^{166}$ Likewise, if any SEC Commissioner could "nominate" an inferior officer for approval by the Commission majority, the Commission would probably select some different officers than those it approved from the more limited pool of nominees acceptable to the agency's Chairman. ${ }^{167}$

Moreover, it is manifestly unclear how inferior officers could be removed under the approbation rule. If an inferior officer is appointed through full board or commission approval after nomination by the chairman, how is the officer removed? May any commissioner or board member call for a vote on the removal of one of these officers? Or may only the chairman initiate removals, just as only the chairman may initiate appointments? For example, the General Counsel of the ITC once advised,

While the commission majority can nullify the chairman's decisions, only the chairman can initiate administrative actions. The ... statute does not permit other commissioners, nor a commission majority, to initiate a purely administrative

163. Volokh, supra note 13, at 774.

164. See supra text accompanying note 121.

165. Reply Brief at 27, Free Enter. Fund v. Public Co. Accounting Oversight Bd., 130 S. Ct. 3138 (2010) (No. 08-861).

166. Does anyone think that the Senate of the 102d Congress, containing fiftyseven Democrats at the time, would have nominated Clarence Thomas to fill Thurgood Marshall's seat on the Supreme Court, even though it narrowly approved his nomination by President George H.W. Bush?

167. See, e.g., U.S. Gen. AcCounting OfFice, GAO-03-339, Securities AND Exchange Commission: Actions NeEded To Improve Public COMPANy ACCOUNTING Oversight BoARD SELECTION PROCESS 10 (2002) (reporting that some SEC Commissioners felt "that their vote was irrelevant" in the current nomination process). 
decision. A commission majority can only block a chairman and not substitute its own decision for the chairman's decision. ${ }^{168}$

Under that vision, the approbation model clearly does not satisfy Justice Scalia's theory of the Appointments Clause, which imagines that "those officers appointed by the President with Senate approval could on their own appoint their subordinates."169 In the case of many agencies, the full boards or commissions, full of Senate-confirmed officers, cannot initiate and appoint subordinates on their own, as they must wait for the chairman to nominate a candidate acceptable to them. It is difficult to see the political accountability or good governance principles in a system whereby a single chairman can block appointments or removals favored by every other commissioner or board member by simply refusing to initiate the process. Where is the collegial decisionmaking that is the alleged raison d'être of multimember agencies? In other words, perhaps this model deserves closer constitutional scrutiny than it has previously received.

Notwithstanding these potential flaws in the approbation theory, even when applied as is, the FMC's limited "authority" to "consult" with its Chairman on appointments ${ }^{170}$ and the ITC's limited power to affirmatively block the Chairman's nominees ${ }^{171}$ do not seem to pass constitutional muster. In sum, after Free Enterprise Fund, the only clearly constitutional inferior officer appointments at multimember agencies are those initiated and approved by the full board or commission, such as those at the Federal Deposit Insurance Corporation ${ }^{172}$ and National Labor Relations Board. ${ }^{173}$ However, most multimember agency appointment schemes do not follow this model.

\section{DEALING WITH THE EFFECTS OF FREE ENTERPRISE FUND}

As Kent Barnett has noted, “An inferior officer’s appointment ... may seem inconsequential. But an invalid appointment could, depending on the [officer's] duties, lead to unnecessary, time-consuming litigation and

168. See U.S. Gen. Accounting OfFice, GAO/NSIAD-92-45, InTERnAtional Trade COMMISSION: ADMINISTRATIVE AUTHORITY Is AMBIGUOUS 16 (1992).

169. See Morrison v. Olson, 487 U.S. 654, 720-21 (1988) (Scalia, J., dissenting) (emphasis added).

170. See 46 U.S.C. § 301(c)(3)(A)(ii) (2006); id. § 301(c)(3)(A)(i); supra text accompanying note 146 .

171. $\quad$ See 19 U.S.C. § 1331(a)(1) (2012); supra text accompanying note 147.

172. 12 U.S.C. § 1819(a) (2006).

173. 29 U.S.C. $\S 154(\mathrm{a})$ (2006). 
perhaps even the invalidation of agency actions.”"174 For example, the Supreme Court has held that "one who makes a timely challenge to the constitutional validity of the appointment of an officer who adjudicates his case is entitled to a decision on the merits of the question and whatever relief may be appropriate if a violation indeed occurred," such as a new hearing "before a properly appointed" adjudicator. ${ }^{175}$ Thus, "most matters in which the [improperly appointed officer] may participatesuch as rulemaking, adjudicatory matters, and enforcement proceedingswould likely be called into question and perhaps even invalidated."176 After all, "[i]f the remedy is not invalidation, it is difficult to see what impetus Congress or the President has to establish proper appointments.”177

Alternatively, perhaps a court would simply find that the improperly appointed inferior officers may be appointed and removed at the discretion of the full board or commission at each respective agency. In Free Enterprise Fund, for example, the Supreme Court noted that "'when confronting a constitutional flaw in a statute, we try to limit the solution to the problem,' severing any 'problematic portions while leaving the remainder intact." "'178

Thus, in Free Enterprise Fund, the Solicitor General argued that if the Chairman was truly the "'Head' of the SEC .... [C]anons of constitutional avoidance would then dictate that [any] statutory grant of appointment authority to 'the Commission' be deemed a grant to its 'Head,' the Chairman." "179 Presumably, the reverse result could also be true-any appointment authorities unconstitutionally vested in a multimember agency chairman could be deemed granted to the board or commission, such that the board or commission could act to appoint and remove or reassign inferior officers from that point forward, without further legislation or litigation. $^{180}$

Otherwise, if Congress would still like the respective chairmen of the various multimember agencies to retain any appointment and removal

174. Barnett, supra note 129 , at 1460.

175. Ryder v. United States, 515 U.S. 177, 182-83, 188 (1995).

176. Barnett, supra note 129, at 1481.

177. Id. at $1483-84$.

178. Free Enter. Fund v. Pub. Co. Accounting Oversight Bd., 130 S. Ct. 3138, 3161 (2010) (quoting Ayotte v. Planned Parenthood of N. New England, 546 U.S. 320, 32829 (2006)); see also Intercollegiate Broad. Sys., Inc. v. Copyright Royalty Bd., 684 F.3d 1332, 1334, 1336-37, 1440-41 (D.C. Cir. 2012), reh'g and reh'g en banc denied, No. 11-1083 (D.C. Cir. Aug. 28, 2012) (striking unconstitutional restrictions on appointment and removal of Copyright Royalty Board members at the Library of Congress but leaving all other statutory provisions intact).

179. Brief for the United States, supra note 114, at 42 n.14.

180. See Free Enter. Fund, 130 S. Ct. at 3161 ("Under the traditional default rule, removal is incident to the power of appointment.”). 
powers over the inferior officers in those agencies, it is free to amend the authorizing statutes to provide for that ${ }^{181}$ because as presidential appointees, chairmen may function as agency heads. ${ }^{182}$ For instance, following the Court's criteria set forth in Free Enterprise Fund, Congress could amend the relevant statutes to place final rulemaking, adjudicatory, and investigatory power in the chairmen-perhaps after consulting with the other board or commission members - and make clear that the chairmen's appointment decisions are not subject to the general policies set forth by their full boards or commissions. ${ }^{183}$ This would provide a way to maintain a board or commission form while making clear that the chairmen are the heads of the agencies. Alternatively, as a kind of stopgap measure, perhaps the current boards and commissions could freely choose to ratify the appointments of their inferior office holders after the fact.

Regardless, as one former commissioner testified to Congress, it is clear that confusing combinations of chairman and board or commission authority are "unworkable." "184 Within the realm of inferior officer appointments, it "simply makes no sense to divide the senior officers of the staff into some appointed and removed by the Commission and others appointed and removed only by the Chairman."185 Another former commissioner agreed that "[o]ne cannot compensate for the absence of a clear majority" in favor of taking certain actions "by changing the law to allow the Chairman to shape the agency," through appointments or otherwise, "to suit his position even if he is in a minority.... [T]he basic authority and tone of the agency and its top employees [must] come from a majority of the Commission." 186

In sum, as a matter of policy and law, it seems clear that an agency should either be led by one strong administrator who is solely responsible for appointing and removing or reassigning the subordinate officials or the agency and all of its inferior officer appointments, removals, and

181. See id. at 3162 (suggesting that "editorial freedom ... belongs to the Legislature" and that "Congress of course remains free to pursue" options restoring the constitutionality of its prior system of appointments).

182. See Printz v. United States, 521 U.S. 898, 922 (1997).

183. See Brief for the United States, supra note 114, at 39-40; supra text accompanying note 115.

184. See Reorganization Plan No. 1 of 1980, supra note 89, at 72 (statement of Victor Gilinsky, Comm'r, Nuclear Regulatory Comm'n).

185. Id. at 80 (statement of Joseph M. Hendrie, Comm'r, Nuclear Regulatory Comm'n)

186. Id. at 75 (statement of Peter A. Bradford, Comm’r, Nuclear Regulatory Comm'n). 
reassignments should be directed by a full board or commission, acting jointly through a majority of its members. After the Supreme Court's decision in Free Enterprise Fund, the alternative mixed structure in place at many multimember agencies is not only unwise but potentially unconstitutional. And even if the world is not falling apart yet, constitutional flaws, by definition, are not matters to be taken lightly.

Congress may therefore wish to take action to remedy these questionable agency appointment provisions, as it jumped to correct the newly identified constitutional flaws in the appointment of administrative patent judges. ${ }^{187}$ Such action would also be consistent with section 989B of the recent Dodd-Frank Wall Street Reform and Consumer Protection Act, which for the first time clarified that the "head of the entity" for the purposes of supervising the inspectors general in twenty-six multimember agencies covered by the Inspector General Act is "the board or commission of the ... entity," rather than the chairmen of those agencies, as the Act had generally been interpreted in the past. ${ }^{188}$ In light of the issues identified above, this was a big step in the right direction.

Perhaps Congress now has its eyes open to other potential agency appointment issues lurking within the U.S. Code. ${ }^{189}$ If so, this Article hopefully presents one more opportunity to correct some constitutionally troubling statutory provisions and continue the pattern of clarifying collective board and commission authorities at multimember agencies.

187. Congress acted quickly in that situation, and perhaps it could do so here as well. See Act of Aug. 12, 2008, Pub. L. No. 110-313, § 1(a)(1), 122 Stat. 3014, 3014 (codified at 35 U.S.C. $§ 6$ (Supp. II 2009)) (remedying constitutional flaw in appointment of patent judges by officers who were not "Heads of Departments," as identified in John F. Duffy, Are Administrative Patent Judges Unconstitutional?, 77 GEO. WASH. L. REV. 904, 919-20 (2009)).

188. See Pub. L. No. 111-203, 124 Stat. 1376, 1945 (2010); see also 2008 and 2009 List of Designated Federal Entities and Federal Entities, 74 Fed. Reg. 3656 (Jan. 21, 2009) (final Office of Management and Budget notice before passage of the Dodd-Frank Act, listing the respective chairmen as the supervisory heads of most multimember entities).

189. See, e.g., James E. Pfander, The Chief Justice, the Appointment of Inferior Officers, and the 'Court of Law' Requirement, 107 Nw. U. L. REV. 1125 (2013) (arguing persuasively that the Supreme Court acting jointly, rather than the Chief Justice acting unilaterally, should possess appointment authority under the Appointments Clause). 


\section{APPENDIXCURRENT APPONTVENT MODELS FORINFERIOR OFFICERS IN MULTIMEMBER AGENCIZS}

\begin{tabular}{|c|c|c|c|c|c|c|c|c|}
\hline Agency & $\begin{array}{l}\text { Inferior Officer } \\
\text { [a] }\end{array}$ & $\begin{array}{l}\text { Appointed } \\
\text { by Board? } \\
{[\mathrm{b}]}\end{array}$ & $\begin{array}{l}\text { Removed } \\
\text { by Bcard? } \\
\text { [c] }\end{array}$ & \begin{tabular}{|l} 
Source of \\
Appointment \\
Authority [d]
\end{tabular} & $\begin{array}{l}\text { Appointment of } \\
\text { Board Requires } \\
\text { Senate } \\
\text { Coniimation? } \\
\text { (Prinz) [e] }\end{array}$ & $\begin{array}{l}\text { Chaiman } \\
\text { Subject to } \\
\text { Board } \\
\text { Fclicies? [f] }\end{array}$ & $\begin{array}{l}\text { Rulenaking, } \\
\text { Adjudicatory, } \\
\text { and } \\
\text { Investgatory } \\
\text { Authority } \\
\text { Vested in } \\
\text { Board? [g] }\end{array}$ & $\begin{array}{l}\text { Chairmar. } \\
\text { Seeected by } \\
\text { President Alone? } \\
\text { (for } \\
\text { Reorganizatior. } \\
\text { Plars) [h. }\end{array}$ \\
\hline $\begin{array}{l}\text { Commodty } \\
\text { Futures } \\
\text { Trading } \\
\text { Commission } \\
\text { (C:TC) } \\
\text { [1] }\end{array}$ & $\begin{array}{l}\text { General } \\
\text { Counsel, } \\
\text { Executive } \\
\text { Director }\end{array}$ & Yes & Yes & $\begin{array}{l}7 \text { U.S.C } \\
\$ 2(a)(4)-(5) \\
(2012)\end{array}$ & \multirow[t]{3}{*}{$\begin{array}{l}\text { Yes: } \\
\text { 7L.SC. } \\
\text { \&2(a)(2)(A) } \\
\text { (2012). }\end{array}$} & \multirow[t]{3}{*}{\begin{tabular}{|l|} 
Yes: \\
7U.S.C. \\
\$2(a)(6)(B) \\
(2012).
\end{tabular}} & \multirow[t]{3}{*}{$\begin{array}{l}\text { Yes: } \\
\text { 7U.S.C. \&2 } \\
\text { (2012) } \\
\text { (generally). }\end{array}$} & \\
\hline $\begin{array}{l}\text { CFTC } \\
{[2]}\end{array}$ & $\begin{array}{l}\text { Heads of Major } \\
\text { Administrative } \\
\text { Units }\end{array}$ & $\begin{array}{l}\text { Yes, after } \\
\text { Chairman } \\
\text { ncminates }\end{array}$ & Unclear & $\begin{array}{l}7 \text { US.C. } \\
\S 2(a)(0)(C) \\
(20.2) .\end{array}$ & & & & \\
\hline $\begin{array}{l}\text { CFTC } \\
{[3]}\end{array}$ & Other officers & Yes & $\overline{Y e s}$ & $\begin{array}{l}7 U S . C . \\
\S 2(a)(7)(A) \\
(20.2) .\end{array}$ & & & & \\
\hline
\end{tabular}




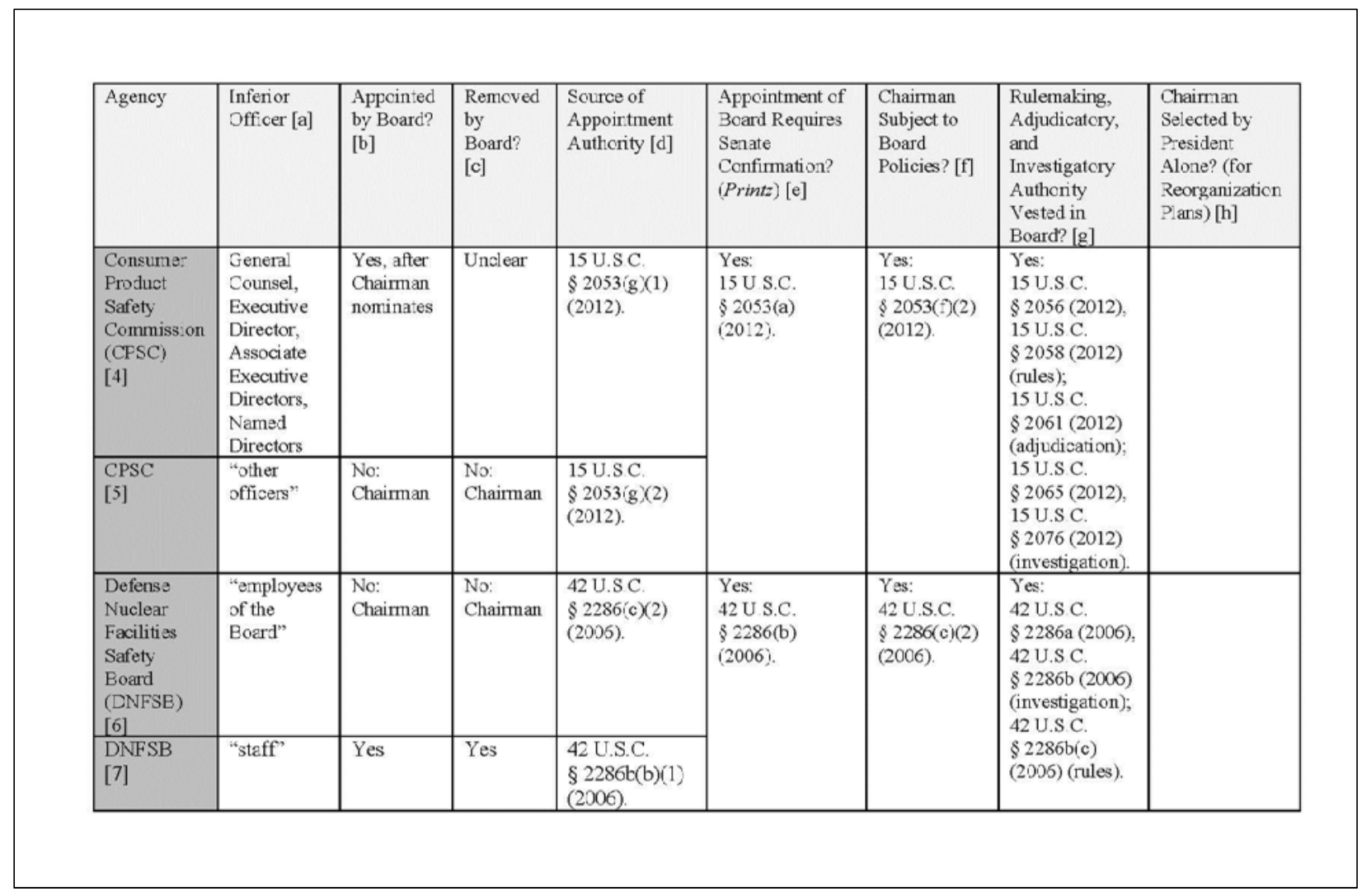




\begin{tabular}{|c|c|c|c|c|c|c|c|c|}
\hline Agency & $\begin{array}{l}\text { Inferior } \\
\text { Officer [a] }\end{array}$ & $\begin{array}{l}\text { Apporited } \\
\text { by Ecard? } \\
\text { [b] }\end{array}$ & \begin{tabular}{|l|} 
Removed \\
by Board? \\
[c]
\end{tabular} & \begin{tabular}{|l|} 
Source of \\
Appointment \\
Authcrity [d]
\end{tabular} & $\begin{array}{l}\text { Appointment of } \\
\text { Board Requres } \\
\text { Senate } \\
\text { Confirmation? } \\
(\text { Priniz })[\mathrm{e}]\end{array}$ & \begin{tabular}{|l|} 
Chairman \\
Sujject to \\
Board \\
Policies? [f]
\end{tabular} & \begin{tabular}{|l|} 
Rulemaking, \\
Adjudicatory, \\
and Investigatory \\
Authority Vested \\
in Board? [g]
\end{tabular} & $\begin{array}{l}\text { Chairman } \\
\text { Selected by } \\
\text { President Alone? } \\
\text { (for } \\
\text { Reorgan zation } \\
\text { Plans) [h] } \\
\end{array}$ \\
\hline $\begin{array}{l}\text { Equal } \\
\text { Enployment } \\
\text { Opportunity } \\
\text { Commission } \\
\text { (EEOC) } \\
{[8]}\end{array}$ & $\begin{array}{l}\text { All } \\
\text { officers }\end{array}$ & $\begin{array}{l}\text { No: } \\
\text { Chairman }\end{array}$ & \begin{tabular}{|l|} 
No \\
Chairman
\end{tabular} & $\begin{array}{l}\text { L2 U.S.C. } \\
\$ 2000 \mathrm{e}-4(\mathrm{a}) \\
(2006) .\end{array}$ & \begin{tabular}{|l|} 
Yes: \\
42 C.S.C. \\
\$2000e-4(a) \\
$(2006)$
\end{tabular} & Unclear & 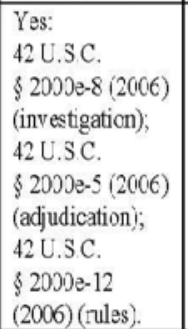 & \\
\hline $\begin{array}{l}\text { Export- } \\
\text { Irport } \\
\text { Bank (ExIm } \\
\text { Bank) } \\
{[9]}\end{array}$ & $\begin{array}{l}\text { Director, } \\
\text { Snall } \\
\text { Busiress } \\
\text { Division }\end{array}$ & $\begin{array}{l}\text { No: } \\
\text { Chairman }\end{array}$ & \begin{tabular}{|l|} 
No: \\
Chairman
\end{tabular} & $\begin{array}{l}\text { 12 U.S.C. } \\
\$ \text { 635a(f)(2) } \\
(2012) .\end{array}$ & \multirow[t]{2}{*}{\begin{tabular}{|l|} 
Yes: \\
12C.S.C. \\
\$ 635aib)-(c) \\
$(2012)$.
\end{tabular}} & \multirow{2}{*}{$\begin{array}{l}\text { Yes, } \\
\text { implied in } \\
\text { that Board } \\
\text { wites } \\
\text { bylaws } \\
\text { governing } \\
\text { agency: } 12 \\
\text { U.S.C. } \\
\text { \$ } 635 \mathrm{a}(\mathrm{c})(7) \\
(2012) \text {. }\end{array}$} & \multirow{2}{*}{$\begin{array}{l}\text { Yes: } \\
\text { :2 U.SC. } \\
\$ 635(\mathrm{~b})(1)(\mathrm{B}) \\
(2012)(\text { set } \\
\text { interest } \\
\text { rates/rules); } 12 \\
\text { U.S.C. } \\
\$ 635(\mathrm{~b})(3) \\
\text { (b)(6)(D)(i), } \\
\text { (b)(7)(2012) } \\
\text { (approve .oans). }\end{array}$} & \\
\hline $\begin{array}{l}\text { Exim } \\
\text { Bank } \\
{[10]}\end{array}$ & $\begin{array}{l}\text { Energy } \\
\text { adviser; } \\
\text { other } \\
\text { officers }\end{array}$ & Yes & Yes & $\begin{array}{l}12 \text { U.S.C. } \\
\$ 535 \mathrm{a}(\mathrm{c})(\mathrm{T}) \\
(2012) .\end{array}$ & & & & \\
\hline
\end{tabular}




\begin{tabular}{|c|c|c|c|c|c|c|c|c|}
\hline Agency & $\begin{array}{l}\text { Infenio: } \\
\text { Officer [a] }\end{array}$ & $\begin{array}{l}\text { Appcined } \\
\text { by Board? } \\
\text { [b] }\end{array}$ & $\begin{array}{l}\text { Remored } \\
\text { by Board? } \\
\text { [c] }\end{array}$ & $\begin{array}{l}\text { Source of } \\
\text { Appointment } \\
\text { Authoity [d] }\end{array}$ & \begin{tabular}{|l|} 
Appointment of \\
Boad Requires \\
Senate \\
Confirraticrer? \\
(Prints) [e]
\end{tabular} & $\begin{array}{l}\text { Chairman } \\
\text { Sutject to } \\
\text { Board } \\
\text { Folicies? } \\
\text { [f] }\end{array}$ & \begin{tabular}{|l|} 
Rulemaking, \\
Adijudicatory, \\
and \\
Investigatory \\
Aut.crity \\
Vested in \\
Board? [g] \\
\end{tabular} & \begin{tabular}{|l} 
Chairman \\
Selected by \\
President Alone? \\
(for \\
Reorganization \\
Plans) [h]
\end{tabular} \\
\hline $\begin{array}{l}\text { Exlm } \\
\text { Bank } \\
\text { [11] }\end{array}$ & $\begin{array}{l}\text { Energy } \\
\text { adviser }\end{array}$ & Yes & Yes & $\begin{array}{l}\text { 12 U.S.C. } \\
\$ 635(\mathrm{~b})(1)(\mathrm{C}) \\
(2012) .\end{array}$ & & & & \\
\hline $\begin{array}{l}\text { Exlm } \\
\text { Bank } \\
{[12]} \\
\end{array}$ & \begin{tabular}{|l|} 
Small \\
business \\
adviser \\
\end{tabular} & Yes & Yes & $\begin{array}{l}12 \text { U.S.C. } \\
\$ 635(\mathrm{~b})(1)(\mathrm{E})(\mathrm{iii}) \\
(2012) .\end{array}$ & & & & \\
\hline $\begin{array}{l}\text { Farm Credit } \\
\text { Adrinistration: } \\
\text { (FCA) } \\
{[13]}\end{array}$ & \begin{tabular}{|l|} 
Heads of \\
administrative \\
divisions
\end{tabular} & $\begin{array}{l}\text { Yes, after } \\
\text { Chairman } \\
\text { nominares }\end{array}$ & Cinclear & $\begin{array}{l}\text { 12 U.S.C. } \\
\text { \&2245(b) (2012). }\end{array}$ & \begin{tabular}{|l} 
Yes: \\
12 U.S.C. \\
\$ 2242(a) \\
(2012).
\end{tabular} & $\begin{array}{l}\text { Yes: } \\
12 \text { U.S.C. } \\
\text { \$2244(a) } \\
(2012) ; \\
12 \text { U.S.C. } \\
\text { \$2244(b) } \\
\text { (2012); } \\
12 \text { U.S.C. } \\
\text { \$2245(a) } \\
\text { (2012). }\end{array}$ & \begin{tabular}{|l} 
Yes: \\
12 U.S C. \\
\&2243(2012) \\
(rulemaking \\
and \\
investigation).
\end{tabular} & \\
\hline
\end{tabular}




\begin{tabular}{|c|c|c|c|c|c|c|c|c|}
\hline Agency & \begin{tabular}{|l|} 
Inferior \\
Officer [a]
\end{tabular} & $\begin{array}{l}\text { Appointed } \\
\text { by Board? } \\
\text { [b] }\end{array}$ & $\begin{array}{l}\text { Renored } \\
\text { by Board? } \\
\text { [c] }\end{array}$ & $\begin{array}{l}\text { Source of } \\
\text { Appointment } \\
\text { Authority [d] }\end{array}$ & $\begin{array}{l}\text { Apporttrent of } \\
\text { Board Requires } \\
\text { Senate } \\
\text { Conirirmaion? } \\
\text { (Prinz) [e] }\end{array}$ & $\begin{array}{l}\text { Chairman } \\
\text { Subject to } \\
\text { Board } \\
\text { Policies? } \\
\text { [f] }\end{array}$ & $\begin{array}{l}\text { Rulemakng, } \\
\text { Adjuicatory, } \\
\text { and Invest gatory } \\
\text { Authority Vested } \\
\text { in Ecard? [g] }\end{array}$ & $\begin{array}{l}\text { Chairman } \\
\text { Selected by } \\
\text { President Alone? } \\
\text { (for } \\
\text { Reorganization } \\
\text { Plans) [hl }\end{array}$ \\
\hline
\end{tabular}

\begin{tabular}{|c|c|c|c|c|c|c|c|c|}
\hline & & & & & & & & Plans [h] \\
\hline $\begin{array}{l}\text { Federal } \\
\text { Communications }\end{array}$ & All officers & Yes & Yes & $\begin{array}{l}\text { 47 U.S.C. } \\
\$ 154(f)(1)\end{array}$ & \begin{tabular}{|l|} 
Yes: \\
$47 \mathrm{C}: \mathrm{SC}$.
\end{tabular} & Unclear & & \\
\hline
\end{tabular}

Commission

(FCD)

[14]

FCC
[15]

Managi

Yes, after

\$154(a) (2005).

\& 154(i)

(rulemakng and

aducication),

47 U.S.C.

\$154(g)(1), (1),

(o), 47 U.S.C.

$\S 403(2006)$

\begin{tabular}{|c|c|c|c|c|c|c|c|}
\hline & & & & & & & (investigation). \\
\hline $\begin{array}{l}\text { Federal Deposit } \\
\text { Insurance } \\
\text { Corporation } \\
\text { (FDIC) } \\
{[16]} \\
\end{array}$ & \begin{tabular}{|l} 
All oficers \\
\end{tabular} & Yes & Yes & $\begin{array}{l}12 \text { U.S.C. } \\
\$ 1819 \text { (a) } \\
\text { (2012). }\end{array}$ & $\begin{array}{l}\text { Yes: } \\
12 \text { L.S C. } \\
\$ 1812(a) \\
(2012) .\end{array}$ & \begin{tabular}{|l|} 
Yes: \\
12 U.S.C. \\
$\S 1819($ a) \\
(2012) \\
(Ecard sets \\
geverning \\
bylaws). \\
\end{tabular} & $\begin{array}{l}\text { Yes: } \\
12 \text { U.S.C. } \\
\$ 1819(\text { a)(2012) } \\
\text { (rulemakng, } \\
\text { investigaion, } \\
\text { and exe-cise all } \\
\text { powers). }\end{array}$ \\
\hline $\begin{array}{l}\text { Federal Election } \\
\text { Commission } \\
\text { (FEC) } \\
{[17]}\end{array}$ & $\begin{array}{l}\text { General } \\
\text { Counsel, } \\
\text { Staff } \\
\text { Director, } \\
\text { others }\end{array}$ & Yes & Yes & $\begin{array}{l}\text { 2U.S.C. } \\
\$ 437 \mathrm{c} \text { (f) } \\
(2012) .\end{array}$ & $\begin{array}{l}\text { Yes: } \\
\text { 2 U.S.C. } \\
\text { \$ 437c(a) } \\
\text { (2012). }\end{array}$ & Unclear & $\begin{array}{l}\text { Yes: } \\
2 \text { U S.C. } \\
\text { \$ 437c(a) (2012) } \\
\text { (investigation, } \\
\text { rulemaking, anc } \\
\text { aducication). }\end{array}$ \\
\hline
\end{tabular}




\begin{tabular}{|c|c|c|c|c|c|c|c|c|}
\hline Agency & $\begin{array}{l}\text { Inferior } \\
\text { Officer [a] }\end{array}$ & $\begin{array}{l}\text { Appointed by } \\
\text { Board? } \\
\text { [b] }\end{array}$ & $\begin{array}{l}\text { Removed } \\
\text { by Board? } \\
\text { [c] }\end{array}$ & $\begin{array}{l}\text { Source of } \\
\text { Appointment } \\
\text { Authority [d] }\end{array}$ & $\begin{array}{l}\text { Appointment of } \\
\text { Board Requires } \\
\text { Senate } \\
\text { Confirmation? } \\
(\text { Printz) [e] }\end{array}$ & $\begin{array}{l}\text { Chairman } \\
\text { Subject to } \\
\text { Board } \\
\text { Policies? } \\
\text { [f] }\end{array}$ & $\begin{array}{l}\text { Rulemaking, } \\
\text { Adjudicatory, } \\
\text { and } \\
\text { Investigatory } \\
\text { Authority } \\
\text { Vested in } \\
\text { Board? }\end{array}$ & $\begin{array}{l}\text { Chairman } \\
\text { Selected by } \\
\text { President Alone? } \\
\text { (for } \\
\text { Reorganization } \\
\text { Plans) [h] }\end{array}$ \\
\hline $\begin{array}{l}\text { Federal } \\
\text { Maritime } \\
\text { Commission } \\
\text { (FMC) } \\
{[18]}\end{array}$ & $\begin{array}{l}\text { All } \\
\text { officers }\end{array}$ & $\begin{array}{l}\text { No } \\
\text { Chairman, } \\
\text { after "consult" } \\
\text { for maajor } \\
\text { crganization } \\
\text { heads }\end{array}$ & Unclear & 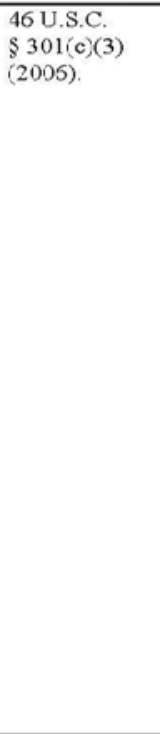 & $\begin{array}{l}\text { Yes: } \\
46 \text { U.S.C. } \\
8301(\mathrm{~b})(1) \\
(2006) .\end{array}$ & $\begin{array}{l}\text { Yes: } \\
46 \text { U. S.C. } \\
\$ 301(\mathrm{c})(2) \\
(2006) .\end{array}$ & $\begin{array}{l}\text { Yes: } \\
46 \text { U.S.C. } \\
\text { \& 306.(2006), } \\
46 \text { U.S.C. } \\
\text { \& 40501(g)(1) } \\
\text { (2005) } \\
\text { (rulemaking); } \\
41 \text { U.S.C. } \\
\text { \& 304 (2006) } \\
\text { (orders); } \\
41 \text { U.S.C. } \\
\text { \& 301(c)(2) } \\
\text { (2005) } \\
\text { (regulatory } \\
\text { decisions); } \\
46 \text { U.S.C. } \\
\text { \& 40103 (2006) } \\
\text { (exemptions); } \\
46 \text { U.S.C. } \\
\text { \& 40104 (2006) } \\
\text { (investigation); } \\
46 \text { U.S.C. } \\
\text { \& 40704 (2006) } \\
\text { (rates); } \\
46 \text { U.S.C. } \\
\text { \& 409.1 (2006) } \\
\text { (licensing). }\end{array}$ & \\
\hline
\end{tabular}




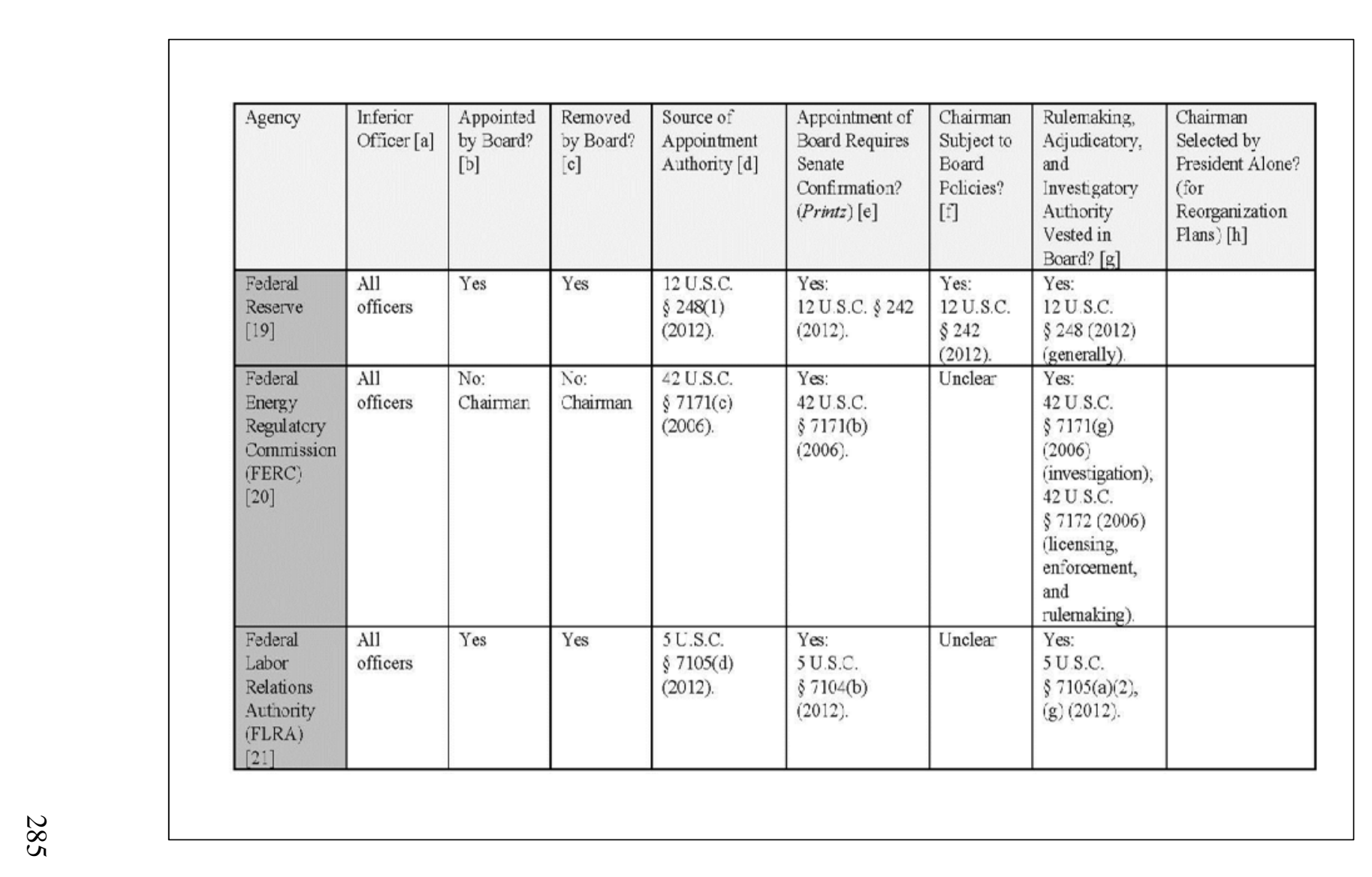




\begin{tabular}{|c|c|c|c|c|c|c|c|c|}
\hline Agency & $\begin{array}{l}\text { Inferior } \\
\text { Officer [a] }\end{array}$ & $\begin{array}{l}\text { Appointed } \\
\text { by 3oard? } \\
\text { [b] }\end{array}$ & $\begin{array}{l}\text { Renoved } \\
\text { by Board? } \\
\text { [c] }\end{array}$ & $\begin{array}{l}\text { Source of } \\
\text { Appointmer: } \\
\text { Authority [d] }\end{array}$ & $\begin{array}{l}\text { Appointment of } \\
\text { Board Requires } \\
\text { Senate } \\
\text { Confirmation? } \\
\text { (Printz) [e] }\end{array}$ & $\begin{array}{l}\text { Chairran } \\
\text { Subjec: to } \\
\text { Board } \\
\text { Policies? } \\
\text { [f] }\end{array}$ & $\begin{array}{l}\text { Rilemaking, } \\
\text { Adjudicatcry, } \\
\text { and Investigatory } \\
\text { Authority Vested } \\
\text { in Boarc? [g] }\end{array}$ & \begin{tabular}{|l|} 
Chairman \\
Selected by \\
Presicent Alone? \\
(for \\
Reorganizator. \\
Plans) [h] \\
\end{tabular} \\
\hline $\begin{array}{l}\text { Federal } \\
\text { Mine Safety } \\
\text { and Health } \\
\text { Review } \\
\text { Commission } \\
\text { (FMSHRC) } \\
\text { [22] }\end{array}$ & $\begin{array}{l}\text { All } \\
\text { officers }\end{array}$ & Yes & Yes & $\begin{array}{l}30 \text { U.S.C. } \\
\text { \$ 823(b)(2) } \\
(2006)\end{array}$ & $\begin{array}{l}\text { Yes: } \\
30 \text { U.S.C. } \\
\text { §823(a) (2006). }\end{array}$ & Unclear & $\begin{array}{l}\text { Yes: } \\
\text { 30 L.S.C. } \\
\text { \$ 823(d) (2C06) } \\
\text { (adjudication and } \\
\text { rulemaking), } \\
\text { 30 C.S.C. } \\
\text { \$ 823(e) (2006) } \\
\text { (invest.gaticr). }\end{array}$ & \\
\hline $\begin{array}{l}\text { Federal } \\
\text { Retirement } \\
\text { Thrift } \\
\text { Investment } \\
\text { Board } \\
\text { (FRTIB) } \\
\text { [23] }\end{array}$ & $\begin{array}{l}\text { Executive } \\
\text { Director }\end{array}$ & Yes & Yes & $\begin{array}{l}\text { 5 U.S.C. } \\
\text { \$ } 8472(\mathrm{~g})(1)(\mathrm{C}) \\
(2012) \text { (removal); } \\
\text { 5 U.S.C. } \\
\text { \$ } 8474(\mathrm{a})(1) \\
\text { (2012) } \\
\text { (appointment). }\end{array}$ & $\begin{array}{l}\text { Yes: } \\
5 \text { U.S.C. } \\
\text { § } 8472(\mathrm{~b}) \\
(2012) .\end{array}$ & Unclear & $\begin{array}{l}\text { Yes: } \\
\text { 5L.S.C. } \\
\text { \$ 8472(f)(1) } \\
\text { (2012)(fules); } \\
\text { 5L.S.C. } \\
\text { \$ 8472(g)(1)(B) } \\
\text { (2012)(direst } \\
\text { staff acticn } \\
\text { regarding rules, } \\
\text { investigations, et } \\
\text { cetera), } \\
\text { 5L.S.C. ₹ } 8475 \\
\text { (2012)(set } \\
\text { policies). } \\
\end{array}$ & \\
\hline
\end{tabular}




\begin{tabular}{|c|c|c|c|c|c|c|c|c|}
\hline Agency & \begin{tabular}{|l|} 
Inferior \\
Officer [a]
\end{tabular} & $\begin{array}{l}\text { Appointed } \\
\text { by Board? } \\
\text { [b] }\end{array}$ & $\begin{array}{l}\text { Rercved } \\
\text { by Bcard? } \\
{[\mathrm{c}]}\end{array}$ & \begin{tabular}{|l} 
Source of \\
Appointment \\
Authcrity [d]
\end{tabular} & \begin{tabular}{|l|} 
Appointment of \\
Board Requires \\
Senate \\
Confirmation? \\
(Prinz) [e]
\end{tabular} & \begin{tabular}{|l|} 
Chairman \\
Subject tc \\
Board \\
Policies? [f]
\end{tabular} & $\begin{array}{l}\text { Ruleraking, } \\
\text { Adjudicetory, } \\
\text { and } \\
\text { Investigatory } \\
\text { Authority } \\
\text { Vested in } \\
\text { Board? [g] }\end{array}$ & \begin{tabular}{|l|} 
Chairman \\
Selected by \\
Presider: Alone? \\
(for \\
Reorganization \\
Plans) [h]
\end{tabular} \\
\hline $\begin{array}{l}\text { Federal } \\
\text { Trade } \\
\text { Commission } \\
\text { (FTC) } \\
{[24]}\end{array}$ & \begin{tabular}{|l|} 
All officers \\
heading \\
major \\
administrative \\
units
\end{tabular} & $\begin{array}{l}\text { Yes, after } \\
\text { Chairman } \\
\text { nominates }\end{array}$ & Unciear & $\begin{array}{l}\text { Reorganization } \\
\text { Plan No. } 8 \text { of } \\
1950 \text { \& 1(b)(2), } \\
\text { 3 C.F.K. 1005 } \\
\text { (1949-1953), } \\
\text { reprinted in } 15 \\
\text { U S.C. \$ } 41 \\
\text { (2012). }\end{array}$ & \begin{tabular}{|l|} 
Yes: \\
15 U.S.C. \& 41 \\
(2012).
\end{tabular} & \begin{tabular}{|l|} 
Yes: \\
Reorganization \\
Plan No. \& of \\
1950 \& 1(b)(1), \\
3 C.F.R. 1005 \\
(1949-1953), \\
reprinted in 15 \\
U S.C. \& 41 \\
(2012).
\end{tabular} & $\begin{array}{l}\text { Yes: } \\
15 \text { U.S.C. \$ } 46 \\
\text { (2012., } 15 \\
\text { U.S.C. \$ } 49 \\
\text { (2012) } \\
\text { (investigation); } \\
15 \text { U.S.C. \$ } 45 \\
\text { (2012), 15 } \\
\text { U.S.C. \& } 53 \\
\text { (2012) } \\
\text { (adjudication); } \\
15 \text { U.S.C. } \\
\text { \& 57a (2012) } \\
\text { (rulemaking). }\end{array}$ & \begin{tabular}{|l} 
Yes: \\
Reorganization \\
Plan No. 8 of \\
$1 S 50$ \$ 3,3 \\
C.F.R 1005 \\
(1949-1953), \\
reprinted in 15 \\
U.S.C. \& 41 \\
(2012).
\end{tabular} \\
\hline $\begin{array}{l}\text { International } \\
\text { Trade } \\
\text { Ccmmission } \\
\text { (ITC) } \\
{[25]}\end{array}$ & All officers & \begin{tabular}{|l|} 
Nc: \\
Chairman, \\
unless \\
Commission \\
disapproves \\
\end{tabular} & $\begin{array}{l}\text { No: } \\
\text { Chairman, } \\
\text { after } \\
\text { Commission } \\
\text { approves }\end{array}$ & $\begin{array}{l}19 \text { U.S.C. } \\
\$ 1331 \text { (a) } \\
\text { (2012). }\end{array}$ & \begin{tabular}{|l} 
Yes: \\
19 U.S.C. \\
\& 1330(a) \\
(2012).
\end{tabular} & Uaclear & $\begin{array}{l}\text { Yes: } \\
\text { 19 U.S.C. } \\
\text { \& 1332 (2012) } \\
\text { (investigation); } \\
\text { 19 U.S.C. } \\
\text { \& 1335 (2012) } \\
\text { (rulemaking); } \\
\text { 19 U.S.C. } \\
\text { \& 1337 (2012) } \\
\text { (adjudicaton). }\end{array}$ & \\
\hline
\end{tabular}




\begin{tabular}{|c|c|c|c|c|c|c|c|c|}
\hline Agency & \begin{tabular}{|l|} 
Inferior \\
Officer [a]
\end{tabular} & $\begin{array}{l}\text { Apponted } \\
\text { by Bcard? } \\
\text { [b] }\end{array}$ & $\begin{array}{l}\text { Removed } \\
\text { by Board? } \\
{[\mathrm{c}]}\end{array}$ & $\begin{array}{l}\text { Source of } \\
\text { Appointment } \\
\text { Authority [d] }\end{array}$ & $\begin{array}{l}\text { Appointment of } \\
\text { Board Requires } \\
\text { Senate } \\
\text { Confirmation? } \\
\text { (Printz) [e] }\end{array}$ & $\begin{array}{l}\text { Chairman } \\
\text { Subject to } \\
\text { Board } \\
\text { Policies? } \\
\text { [f] }\end{array}$ & $\begin{array}{l}\text { Rulemaking, } \\
\text { Adjudicatory, } \\
\text { anc Investigatory } \\
\text { Authority Vested } \\
\text { in Board? [g] }\end{array}$ & $\begin{array}{l}\text { Chairman } \\
\text { Selected by } \\
\text { President Alone? } \\
\text { (for } \\
\text { Recrganization } \\
\text { Plans) [h] }\end{array}$ \\
\hline $\begin{array}{l}\text { Merit Systems } \\
\text { Protection } \\
\text { Boarc (MSPB) } \\
{[26]}\end{array}$ & $\begin{array}{l}\text { All } \\
\text { officers }\end{array}$ & $\begin{array}{l}\text { No: } \\
\text { Chairman }\end{array}$ & $\begin{array}{l}\text { No: } \\
\text { Chairman }\end{array}$ & $\begin{array}{l}5 \text { U.S.C. } \\
\$ 1204(\mathrm{j}) \\
(2012) .\end{array}$ & $\begin{array}{l}\text { Yes: } \\
5 \text { U.S.C. \& } 1201 \\
(2012) .\end{array}$ & Unclear & 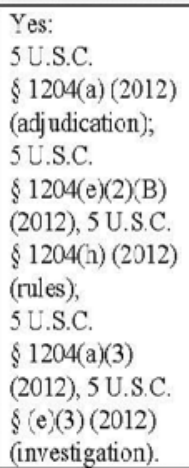 & \\
\hline $\begin{array}{l}\text { Nationa } \\
\text { Credi: Union } \\
\text { Administration } \\
\text { (NCUA) } \\
\text { [27] }\end{array}$ & $\begin{array}{l}\text { All } \\
\text { officers }\end{array}$ & Yes & Yes & $\begin{array}{l}12 \text { U.S.C. } \\
\text { \$ 1765(i)(1) } \\
(2012) ; 12 \\
\text { U.S.C. } \\
\S 1765(\mathrm{j})(1) \\
(2012) .\end{array}$ & $\begin{array}{l}\text { Yes: } \\
12 \text { U.S.C. } \\
\$ 1752 \mathrm{a}(\mathrm{b}) \\
(2012) .\end{array}$ & $\begin{array}{l}\text { Yes: } \\
12 \text { U.S.C. } \\
\$ 1752 a(d) \\
(2012) .\end{array}$ & $\begin{array}{l}\text { Yes: } \\
12 \text { U.S.C. \& } 1766 \\
\text { (2012) } \\
\text { (rulemakng, } \\
\text { adjudication, and } \\
\text { investigation). }\end{array}$ & \\
\hline
\end{tabular}




\begin{tabular}{|c|c|c|c|c|c|c|c|c|}
\hline Agercy & \begin{tabular}{|l|} 
Inferior \\
Officer [a]
\end{tabular} & $\begin{array}{l}\text { Appointed } \\
\text { by Board? } \\
\text { [b] }\end{array}$ & $\begin{array}{l}\text { Removed } \\
\text { by Boarc?? } \\
\text { [c] }\end{array}$ & $\begin{array}{l}\text { Source of } \\
\text { Appointment } \\
\text { Authority [d] }\end{array}$ & $\begin{array}{l}\text { Appointment of } \\
\text { Board Requires } \\
\text { Senate } \\
\text { Confirmation? } \\
(\text { Printz })[\mathrm{e}]\end{array}$ & $\begin{array}{l}\text { Chairman } \\
\text { Subject to } \\
\text { Bcard } \\
\text { Policies? } \\
\text { [f] }\end{array}$ & $\begin{array}{l}\text { Rulemaking, } \\
\text { Adjudicato:y, } \\
\text { and } \\
\text { Irvestigato:y } \\
\text { Authority } \\
\text { Vested in } \\
\text { Board? [g] }\end{array}$ & \begin{tabular}{|l} 
Chairman \\
Selected by \\
President Alone? \\
(for \\
Recrganization \\
Plans) [t]
\end{tabular} \\
\hline $\begin{array}{l}\text { lational } \\
\text { Labor } \\
\text { Relations } \\
\text { Bcard } \\
\text { (NLRB) } \\
\text { [28] }\end{array}$ & \begin{tabular}{|l|} 
All \\
officers
\end{tabular} & Yes & Yes & $\begin{array}{l}29 \text { U.S.C. } \\
\& 154(\mathrm{a}) \\
(2006)\end{array}$ & \begin{tabular}{|l|} 
Yes: \\
29 U.S.C. \\
$\$ 153$ (a) (2006).
\end{tabular} & Unclear & $\begin{array}{l}\text { Yes: } \\
29 \text { U.S.C. } \\
\text { \$ } 156 \text { (2006) } \\
\text { (rulemaking); } \\
29 \text { U.S.C. } \\
\text { \$155 (2006), } \\
29 \text { U.S.C. } \\
\text { \$ } 161 \text { (2006) } \\
\text { (investigation); } \\
29 \text { U.S.C. } \\
\text { \$ } 160 \text { (2006) } \\
\text { (adjudication). }\end{array}$ & \\
\hline $\begin{array}{l}\text { National } \\
\text { Mediaticr. } \\
\text { Bcard } \\
\text { (NMB) } \\
\text { [29] }\end{array}$ & $\begin{array}{l}\text { All } \\
\text { officers }\end{array}$ & Yes & Yes & $\begin{array}{l}45 \text { U.S.C. } \\
\S 154 \text { (2006). }\end{array}$ & $\begin{array}{l}\text { Yes: } \\
45 \text { U.S.C. } \$ 154 \\
(2006) .\end{array}$ & Unclear & $\begin{array}{l}\text { Yes: } \\
45 \text { U.S.C. } \\
\text { \$ } 155 \text { (2006) } \\
\text { (rame } \\
\text { artitrator), } \\
45 \text { U.S.C. } \\
\text { \$ } 156 \text { (2006) } \\
\text { (rulemaking). }\end{array}$ & \\
\hline
\end{tabular}




\begin{tabular}{|c|c|c|c|c|c|c|c|c|}
\hline Agency & $\begin{array}{l}\text { Infericr Officer } \\
\text { [a] }\end{array}$ & $\begin{array}{l}\text { Appcintec } \\
\text { by Board? } \\
\text { [b] }\end{array}$ & $\begin{array}{l}\text { Rernoved by } \\
\text { Eoard? } \\
\text { [c] }\end{array}$ & $\begin{array}{l}\text { Source of } \\
\text { Appointment } \\
\text { Authority [d] }\end{array}$ & $\begin{array}{l}\text { Appointment of } \\
\text { Board Requires } \\
\text { Senate } \\
\text { Confirmation? } \\
\text { (Prinz) [e] }\end{array}$ & $\begin{array}{l}\text { Cheiman } \\
\text { Subject to } \\
\text { Eoard } \\
\text { Folicies? [f] }\end{array}$ & $\begin{array}{l}\text { Rilemaking, } \\
\text { Adudication, } \\
\text { and } \\
\text { Investigatory } \\
\text { Authority } \\
\text { Vested in } \\
\text { Boarc? [s] }\end{array}$ & $\begin{array}{l}\text { Chairman } \\
\text { Selected by } \\
\text { President Alone? } \\
\text { (for } \\
\text { Reorganzatior. } \\
\text { Plans) [h] }\end{array}$ \\
\hline $\begin{array}{l}\text { Nuclear } \\
\text { Regulatory } \\
\text { Commission } \\
\text { (NRC) } \\
\text { [3C] }\end{array}$ & $\begin{array}{l}\text { General } \\
\text { Counsel, } \\
\text { Executive } \\
\text { Director, } \\
\text { Secretary, } \\
\text { Acrnnistraive } \\
\text { Judges, Chief } \\
\text { Financial } \\
\text { Officer, } \\
\text { Deputy Chief } \\
\text { Financial } \\
\text { Officer, various } \\
\text { office directors } \\
\end{array}$ & $\begin{array}{l}\text { Yes, after } \\
\text { Chairman } \\
\text { nominates }\end{array}$ & $\begin{array}{l}\text { Yes, after any } \\
\text { Commissioner } \\
\text { nominates }\end{array}$ & $\begin{array}{l}\text { Resgganization } \\
\text { Plan 1 of } 1980 \\
\text { \$1(b), } 45 \text { Fed. } \\
\text { Reg. 40551 } \\
\text { (Mar. 27, } \\
\text { 1980). }\end{array}$ & \multirow[t]{2}{*}{$\begin{array}{l}\text { Yes: } \\
\text { 42 U.S.C. } \\
\text { \& 5841(a)(1) } \\
\text { (2006). }\end{array}$} & \multirow[t]{2}{*}{$\begin{array}{l}\text { Yes: } \\
\text { Recrganizaticn } \\
\text { Flan } 1 \text { of } 1980 \\
\text { \$2(c), } 45 \text { Fed. } \\
\text { Reg. 40561 } \\
\text { (Mar. 27, } \\
\text { 1980). }\end{array}$} & \multirow[t]{2}{*}{$\begin{array}{l}\text { Yes: } \\
\text { Reorganization } \\
\text { Plang I of } 1980 \\
\text { \&1(a), } 45 \text { Fed. } \\
\text { Reg. } 40561 \\
\text { (Mar. 27, } \\
\text { 1980); } \\
\text { 42 L.S.C. } \\
\text { \&2201(c) } \\
\text { (2006) }\end{array}$} & \multirow[t]{2}{*}{$\begin{array}{l}\text { Yes: } \\
42 \text { U.S.C. } \\
\$ 5841(a)(1) \\
(2006) .\end{array}$} \\
\hline $\begin{array}{l}\text { NRC } \\
{[31]}\end{array}$ & $\begin{array}{l}\text { Public Affairs, } \\
\text { Congressional } \\
\text { Affairs }\end{array}$ & $\begin{array}{l}\text { No: } \\
\text { Chairman }\end{array}$ & $\begin{array}{l}\text { No: } \\
\text { Chairman }\end{array}$ & $\begin{array}{l}\text { Resrganization } \\
\text { Plan } 1 \text { of } 1980 \\
\text { \$2(a), } 45 \text { Fed } \\
\text { Reg. } 40561 \\
\text { (Mar. 27, } \\
\text { 1980). }\end{array}$ & & & & \\
\hline
\end{tabular}









\begin{tabular}{|c|c|c|c|c|c|c|c|c|}
\hline Agency & \begin{tabular}{|l|} 
Infericr \\
Officer [a]
\end{tabular} & $\begin{array}{l}\text { Appointed } \\
\text { by Board? } \\
\text { [b] }\end{array}$ & $\begin{array}{l}\text { Removed } \\
\text { by Board? } \\
\text { [c] }\end{array}$ & $\begin{array}{l}\text { Scurce of } \\
\text { Appointment } \\
\text { Authority } \\
\text { [d] }\end{array}$ & $\begin{array}{l}\text { Appointment } \\
\text { of Board } \\
\text { Requires } \\
\text { Senate } \\
\text { Confirmation? } \\
\text { (Printz) [e] }\end{array}$ & $\begin{array}{l}\text { Chairman } \\
\text { Subject to } \\
\text { Board } \\
\text { Policies? } \\
\text { [f] }\end{array}$ & $\begin{array}{l}\text { Rulemaking, } \\
\text { Adjudicatory, } \\
\text { and } \\
\text { Investigatory } \\
\text { Authority } \\
\text { Vested in } \\
\text { Board? [g] }\end{array}$ & $\begin{array}{l}\text { Chairman } \\
\text { Selected by } \\
\text { President } \\
\text { Alone? (for } \\
\text { Reorganization } \\
\text { Plans) [h] }\end{array}$ \\
\hline $\begin{array}{l}\text { Occupational } \\
\text { Safety and } \\
\text { Health } \\
\text { Review } \\
\text { Commission } \\
\text { (OSHRC) } \\
\text { [35] }\end{array}$ & $\begin{array}{l}\text { All } \\
\text { officers }\end{array}$ & $\begin{array}{l}\text { No: } \\
\text { Chairman }\end{array}$ & $\begin{array}{l}\text { No: } \\
\text { Chairman }\end{array}$ & $\begin{array}{l}29 \text { U.S.C. } \\
\$ 661(\mathrm{e}) \\
(2006) .\end{array}$ & $\begin{array}{l}\text { Yes: } \\
29 \text { U.S.C. } \\
\$ 661 \text { (a) } \\
(2005)\end{array}$ & Unclear & $\begin{array}{l}\text { Yes: } \\
29 \text { U.S.C. } \\
\$ 661(\mathrm{~g}) \\
(2006)(\text { rules); } \\
29 \text { U.S.C. } \\
\$ 661 \text { (h)-(i) } \\
\text { (2006) } \\
\text { (investigation); } \\
29 \text { U.S.C. } \\
\$ 659 \text { (c) } \\
\text { (2006) } \\
\text { (adjudication). }\end{array}$ & \\
\hline $\begin{array}{l}\text { Postal } \\
\text { Regulatory } \\
\text { Commission } \\
\text { (PRC) } \\
{[36]}\end{array}$ & $\begin{array}{l}\text { All } \\
\text { officers }\end{array}$ & $\begin{array}{l}\text { No: } \\
\text { Chairman, } \\
\text { with } \\
\text { Commission } \\
\text { approval for } \\
\text { major } \\
\text { organization } \\
\text { heads }\end{array}$ & Unclear & $\begin{array}{l}39 \text { U.S.C. } \\
\$ 504(a)(1) \\
(2006) .\end{array}$ & $\begin{array}{l}\text { Yes: } \\
\text { 39 U.S.C. } \\
\$ 502(a) \\
(2005)\end{array}$ & $\begin{array}{l}\text { Yes: } \\
39 \text { U.S.C. } \\
\$ 504(\mathrm{~b}) \\
(2005)\end{array}$ & $\begin{array}{l}\text { Yes: } \\
39 \text { U.S.C. } \\
\$ 503 \text { (2006) } \\
\text { (rules/actions); } \\
\text { 39U.S.C. } \\
\$ 504(\text { f) } \\
\text { (2006) } \\
\text { (approve } \\
\text { Chairman } \\
\text { subpoenas) }\end{array}$ & \\
\hline $\begin{array}{l}\text { Railroad } \\
\text { Retirement } \\
\text { Board } \\
\text { [37] }\end{array}$ & $\begin{array}{l}\text { All } \\
\text { officers }\end{array}$ & Yes & Yes & $\begin{array}{l}45 \text { U.S.C. } \\
\$ 231 \mathrm{f}(\mathrm{b})(9) \\
(2006) .\end{array}$ & $\begin{array}{l}\text { Yes: } \\
45 \text { U.S.C. } \\
\$ 231 \text { f(a) } \\
\text { (2005) }\end{array}$ & Unclear & $\begin{array}{l}\text { Yes: } \\
45 \text { U.S.C. } \\
\$ 231 \mathrm{f}(\mathrm{b}) \\
\text { (2006) (all } \\
\text { powers). }\end{array}$ & \\
\hline
\end{tabular}




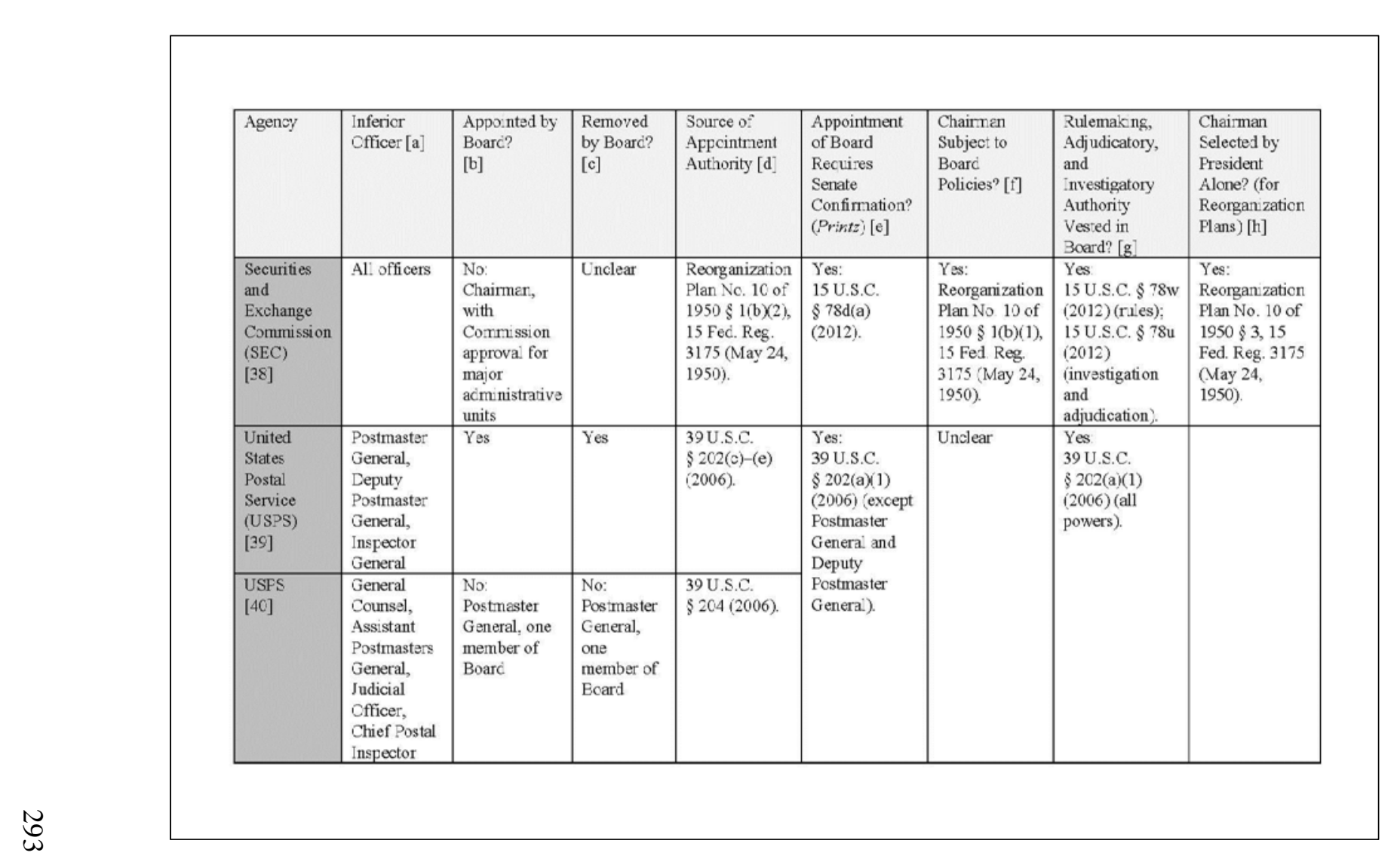


